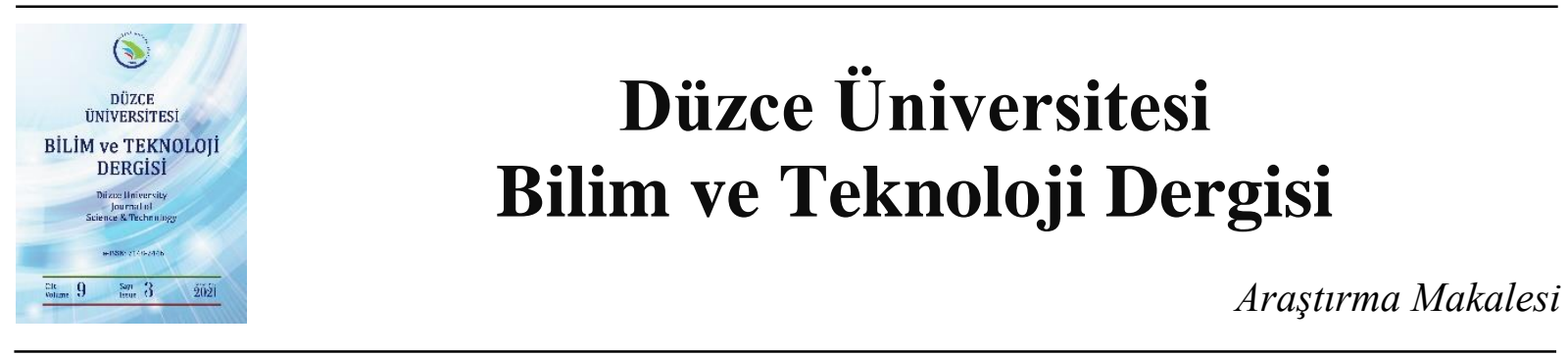

\section{İç Mekân Konfor Şartlarının AVM (Alışveriş Merkezi) Çalışanları Üzerindeki Etkileri}

\author{
DEbru İLDEŞ, (DF. Dila TAŞDEMIR, (DFiliz UMAROĞULLARI ${ }^{\text {a, * }}$ \\ ${ }^{a}$ Mimarlı Bölümü, Mimarlık Fakültesi, Trakya Üniversitesi, Edirne, TÜRKIYE \\ *Sorumlu yazartn e-posta adresi: filizu@trakya.edu.tr
}

DOI: 10.29130/dubited.755756

\begin{abstract}
ÖZET
İklim koşullarından etkilenmeden alışveriş, eğlenme, sosyalleşme gibi fonksiyonlara tek bir mekânda erişebilme imkânı sunması nedeniyle kapalı alışveriş merkezleri günümüzde yaşamın bir parçası haline gelmiştir. Ancak konforlu iç mekân koşulları sağlamak amacıyla bu mekânlar gün boyu yapay aydınlatma ve iklimlendirme sistemleri ile desteklenmektedir. İnsanların fizyolojik ve psikolojik dengesinde önemli rol oynayan günışığından yeterince faydalanamayan bu mekânlarda çalışan kişilerde kronik hale gelen bazı sağlık sorunları görülmesi olasıdır. Alışveriş merkezi (AVM) kullanıcıları kısıtlı bir zaman içerisinde bu koşullara maruz kalırken AVM çalışanları gün boyu bu koşullardan etkilenmektedir. Bu çalışma ile AVM'lerde çalışanların fiziksel konfor değerlendirmesi yapılarak, konfor parametrelerinin kullanıcıya etkileri bağlamında çıkarımlar elde etmek, yeterli konfor düzeyine ulaşılabilirlik konusunda önerilerde bulunarak, sağlıklı bir toplumsal yaşam için katkı sağlamak amaçlanmıştır. Bu amaçla örneklem olarak Edirne'de seçilen 500 kişilik çalışan grubu olan bir AVM'de çalışanların iç ortamın ısıl konfor, iç hava kalitesi, görsel ve işitsel konfor durumlarını belirlemek amacıyla 240 katılımcıya anket uygulanmış ve elde edilen sonuçların istatistiksel analizi yapılmıştır. Çalışmanın sonucunda AVM çalş̧anlarının \%26,7'si ısıl konforun uygun bulmamıştır. ASHRAE 55'e göre \%80, TS EN ISO 7730'a göre \%90'ının ortam koşullarından memnun olduğu durum konforlu olarak kabul edilmektedir. Bu durumda AVM'nin 1sıl konfor durumu uygun değildir. İç hava kalitesi açısından çalışanların \%21-37 oranında rahatsızlık duyduğu ve bu durumun çalışllan mağaza türü, kat ve sigara içme gibi faktörlere bağlı olarak değişkenlik gösterdiği tespit edilmiştir. Görsel konfor açısından çalışanların $\% 65$ 'inin gün içerisinde gün 1şığından yeteri kadar faydalanamadığı ancak yapay aydınlatma koşullarını \%67 oranında uygun bulduğu görülmüştür. İşitsel konfor açısından çalışanların \%80'i memnun değildir. Gürültü kaynağının ise çoğunlukla iç ortam kaynaklı olduğu anlaşılmaktadır. Atriumlu kapalı planlı bir AVM örneğinde gerçekleştirilen bu çalışma sonucunda tasarım ve planlama aşamasında doğal havalandırma ve aydınlatma çözümlerine önem verilmesi çalışanlarının işlerini daha sağlıklı ve verimli bir şekilde sürdürebilmesi açısından önemlidir.
\end{abstract}

Anahtar Kelimeler: Isll konfor, İ̧ hava kalitesi, Görsel konfor, Işsitsel konfor, AVM

\section{The Effects of Indoor Comfort Conditions on the Employees in the Shopping Malls}

\begin{abstract}
Closed shopping malls (SM) have become a part of life today as it offers access to functions such as shopping, entertainment and socialization without being affected by climate conditions in a single place. However, these spaces are supported by artificial lighting and air conditioning systems throughout the day in order to provide comfortable interior conditions. It is possible to see some chronic health problems in these people who do not
\end{abstract}


benefit enough from daylight, which plays an important role in the physiological and psychological balance of people. Shopping malls users are exposed to these conditions within a limited time, while SM employees are affected by these conditions throughout the day. With this work, by evaluating the physical comfort of employees in shopping malls, obtaining inferences in the context of the effects of comfort parameters to the user, and making recommendations on the availability of adequate level of comfort, it is aimed to contribute to a healthy social life. For this purpose, a questionnaire was applied to 240 participants in order to determine the thermal comfort, indoor air quality, visual and auditory comfort conditions of the employees in a shopping mall with 500 employees selected as a sample in Edirne and the results obtained were statistically analyzed. As a result of the study, 26.7\% of the shopping mall employees did not find thermal comfort suitable. The situation where $80 \%$ according to ASHRAE 55 and $90 \%$ according to TS EN ISO 7730 are satisfied with the ambient conditions is considered comfortable. In this case, the thermal comfort condition of the shopping mall is not suitable. In terms of indoor air quality, it has been determined that 21-37\% of employees feel uncomfortable and this situation varies depending on factors such as the type of store they work, floor and smoking. In terms of visual comfort, it was observed that $65 \%$ of the employees could not benefit from daylight sufficiently during the day but found the artificial lighting conditions suitable by $67 \% .80 \%$ of the employees are not satisfied in terms of auditory comfort. It is understood that the noise source is mostly indoor. As a result of this study carried out in an example of a shopping mall with an atrium in a closed plan, it is important to give importance to natural ventilation and lighting solutions in the design and planning phase in order for employees to continue their work in a healthier and more efficient way.

Keywords:Thermal comfort, Indoor air quality, Visual comfort, Acustic comfort, Shopping malls

\section{GIRIS}

Konfor mekân kullanıcılarının memnuniyetinin belirtisidir. İnsanların sağlıklı ve mutlu bir hayat sürebilmesi için yapıların sıcaklık, nem, iç hava kalitesi, aydınlatma, ses ile ilgili konularda optimum koşulları sağlaması gerekmektedir [1-3]. İç mekân konfor koşulları sürdürülebilirliğin ana unsurlarından olup kullanıcılar için iyi bir yaşam kalitesinin sağlanmasında da en önemli etkenlerdendir. Ancak bu koşullar sağlanırken sürdürülebilirliğin gerekliliklerinden biri olan en az enerji kullanımı ile sağlanmasına yönelik çözümlerin mimari tasarıma aktarılması da büyük önem taşımaktadır [4]. Yapıların fonksiyonu ile örtüşecek şekilde 1s1, nem, hava kalitesi, 1şık, ses vb. parametrelerin belirli değerlerde olması zorunludur. Bu konfor parametreleri; 1sıl konfor, iç hava kalitesi, görsel konfor, işitsel konfor olarak sinıflandırılabilir [5-6].

Isı1 konforu genel olarak çevresel ve kişisel parametreler belirler. Ortam sıcaklığı, bağıl nemi, hava hızı ve ortalama radyan sıcaklık çevresel parametreler olarak adlandırılır; kişisel parametreler ise kişinin metabolik aktivite seviyesi ve giysilerinin yalıtım değeri ile belirlenir [7-8]. ASHRAE 55 standardına göre konfor aralıkları; kışın sıcaklık $20^{\circ} \mathrm{C}$ ile $23,6^{\circ} \mathrm{C}$, bağıl nem $\% 30-65$ arası ve hava akış hızının $<0,15$ $\mathrm{m} / \mathrm{sn}$, yazın ise sıcaklık $22,8^{\circ} \mathrm{C}$ ile $26,1^{\circ} \mathrm{C}$, bağıl nem $\% 20-60$ arası ve hava akış hızı $>0,25 \mathrm{~m} / \mathrm{sn}$ olarak kabul edilmektedir [9]. İnsan vücudu, bulunduğu ortamın iklim koşullarından hızlı bir şekilde etkilenerek düşük ve yüksek hava sıcaklıklarına karşı tepki gösterir. Ortamın yüksek sıcaklıkta olması kişilerde yorgunluk hissi ve uyuklamaya neden olmakta, düşük sıcaklıktaki ortamlar ise; motivasyon eksikliği, bedensel ve zihinsel verimin düşmesine sebep olmaktadır [10]Ortamda bağıl nem oranının yüksek olması ise toz akarlarının ve küf mantarlarının çoğalmasına neden olarak alerjik reaksiyonlar başta olmak üzere, nefes alıp vermede zorlanma, hırıltılı soluma, burun ve geniz akıntısı, hapşırma, öksürme, kaşıntı, gözde sulanma, baş dönmesi, aşırı yorgunluk, deri ve saçlarda kuruma gibi belirtilerle insan sağlı̆̆ını olumsuz şekilde etkiler[11]. Nem oranının düşük olduğu ortamda ise statik elektrik artarak tozların havada asılı kalmasına ve insanlarda nefes alma zorluğuna yol açar [10]. İç ortama ait bu nesnel parametrelerin yanı sıra kullanıcıların cinsiyeti ve yaşı gibi birçok faktöre bağlı olarak konfor durumu değişmektedir. PMV-PPD modeli ısıl konfor için bir endeks olarak kabul edilmektedir. Fanger tarafindan oluşturulan ve ASHRAE modeliyle örtüşen PMV modelinde, ideal durumu 0 olan -3 ile +3 arasındaki rakamlardan oluşan 7 adımlı indeks tanımlanarak, bireyin psikofiziksel 1sıl duyarlılığını ölçmek amaçlanmıştır. İdeal duruma (0'a) yaklaştıkça indeks mutlak değeri küçülüp, ideal durumdan uzaklaştıkça indeks mutlak değeri büyümektedir. Fanger, 7 nokta termal duyarlılık ölçeği ile bir topluluk için en az \%80'inin memnuniyetini sağlayacak konfor sıcaklığını bulmayı amaçlamıştır ve $+1,0,-1$ oyları konforlu olarak belirtilmiştir [12]. ASHRAE 55 standardına göre, iç mekân kullanıcılarının 
$\%$ 80'inin, TS EN ISO 7730'da ise \%90'ının konfor koşullarını uygun kabul ettiği durum konforlu kabul edilir [9-16]. Isıl konfor aynı zamanda mekân kullanıcılarının verimliliği ve üretkenliği üzerinde de önemli bir etkendir [17-19].

Konforlu bir yaşam ortamı sağlayabilmek için yalnızca 1sıl konforun uygun düzeyde olması yeterli değildir. İç ortam havasında insan sağlığını olumsuz yönde etkileyen kirleticilerin belirli seviyeleri aşmaması beklenir. ASHRAE 55 standardına göre $\mathrm{CO}_{2}$ seviyesinin $1000 \mathrm{ppm}$ değerini aşmaması ve partikül madde miktarının $75 \mu \mathrm{g} / \mathrm{m}^{3}$ 'den küçük olması gerekmektedir [9]. Yapılan çalışmalar, iç ortam havasının, dış havanın kirlilik seviyesinden çok daha fazla kirli olabileceğini ve insan sağlığına zararlı gaz ve partiküller içerdiğini kanıtlamıştır [20]. Kirleticiler, dış ortamda oluşup iç ortama girebileceği gibi iç mekân kaynaklıda olabilir. Dış ortam kaynaklı hava kirleticileri; biyolojik kirleticiler, uçucu organik bileşikler, $\mathrm{SO}_{\mathrm{x}}$ (kükürt oksitler), $\mathrm{O}_{3}$ (ozon), çoğunlukla motorlu taşıtların sebep olduğu kurşunlu bileşikler, hidrokarbonlar ve benzen, $\mathrm{NO}_{\mathrm{x}}$ (azot oksitler), karbonlu bileşenler ve $\mathrm{Rn}$ (radon)' dur [6]. İç ortam kaynaklı hava kirleticileri ise, yapı bileşenleri, döşeme ve dekorasyon malzemelerinden gelen kirleticiler, insan ve makine aktiviteleri ile ortaya çıkan kirleticiler, dış ortamdan iç ortama havalandırma ve hava sızıntısı ile geçen gaz, mantar, küf, ev tozu, haşereler gibi biyolojik ve kimyasal kirleticilerdir. [21-23]. Bunların bazıları koku vb. belirtiler ile kullanıcılar tarafından fark edilebilirken büyük bir kısmı ise baş ağrısı, baş dönmesi, kronik yorgunluk, göz, burun ve boğaz tahribat1, solunum sistemi hastalıkları, gibi bazı sağlık semptomları ile fark edilebilmektedir [24-31]. Bunun sonucunda; bina ile İlişkili hastalıklar, HBS (Hasta Bina Sendromu), Kawasaki ve Kakosmi Sendromu gibi hastalıkların ya da ölümlerin görülme sıklığının arttığı, konsantrasyonun düştüğü, sağlık masraflarının arttığı görülmektedir [6,22-24,29, 32].

Görsel konforun yani iyi görme koşullarının sağlanması doğal ve yapay aydınlatmanın nicelik ve nitelik yönünden gereken koşulların oluşturulmasıyla olanaklıdır. Gün ışığı, insanda fizyolojik ve davranışsal olayların uyumlu bir şekilde devamlılığını sağlamak için üretilen ritim olan 24 saatlik sirkadyan döngü sisteminde etkili bir uyarıcıdır. Bu sistem 24 saatlik aralıklarla tekrarlanan uyku-uyanıklık döngüsü gibi değişmeler veya tekrarlardır. Karanlık ve aydınlık gibi günışığına bağlı faktörlerle düzenlenir. Yapılarda doğal aydınlatmanın doğru uygulanması kullanıcı sağlığının, psikolojik, fizyolojik konforun ve iş verimliliğinin artmasında etkisi büyüktür. İyi bir aydınlatma, kamaşma kontrolü sağlaması ve aydınlık seviyesinin gün içindeki niceliksel ve niteliksel değişiklikleri saptaması ile görsel konforun artmasını sağlamaktadır [33-34]. Amacına uygun olarak aydınlatılmış ortamlar görsel performansı desteklemenin yanı sıra insanlarda olumlu duyguların oluşmasına da katkıda bulunmaktadır. Yetersiz ve az aydınlatılmış ortamlar ise; görsel performansın düşmesine, algıda yanılgılara, konforsuzluğa ve sağlık sorunlarına neden olabilmektedir [35]. Türkiye'de yapı içi aydınlık düzeyleri 'TS EN 12464-1 Işık ve Işı1klandırma- İş Mahallerinin Aydınlatılması-Bölüm 1: Kapalı Alandaki İş Mahalleri’nde belirtilmiştir. Ancak kış ve bahar dönemlerinde yapılan deneylerde gözlenen değişkenliklerden de anlaşılacağı üzere yapı içi aydınlık düzeyleri kullanıcı gereksinimlerine göre farklılık göstermektedir. Bu farklııı̆ın nedeni kişilerin 1şığa duyarlılı̆̆ı, uyku kalitesi, biyolojik saati gibi durumlardır.

Mekânlarda konforu belirleyen bir diğer etken ise işitsel konfordur. Bir mekân içerisinde insan iç mekân veya dış mekân kaynaklı farklı seslere maruz kalmaktadır. Ses düzeyinin yüksekliği veya düzensiz sesler insan üzerinde fizyolojik ve psikolojik olumsuz etkilere neden olabilmektedir. İşitsel konfor subjektif bir durum olup insanların yaşına, cinsiyetine, içinde bulundukları psikolojik ve fizyolojik duruma ve daha birçok faktöre göre farklılık göstermektedir. İşitsel konfor koşulları oluşmadığında duyma organlarında rahatsızlıklar, zihinsel algılama ve öğrenmede bozukluklar, konsantrasyon bozukluğu, performans düşüklüğü gibi etkilerin ortaya çıkması işitsel konforun önemini ortaya koymaktadır [36].

Günümüzde AVM'ler kullanıcılar için yaşamın önemli bir parçası haline gelmiştir. Kapalı mekânlardan oluşan ve çoğunlukla yapay aydınlatma, mekanik iklimlendirme koşullarında hizmet sunan bu karmaşık ve büyük ölçekli yapılarda kullanıcıların konfor durumu pek çok araştırmanın konusunu oluşturmaktadır. Alışveriş amaçlı kullanıcıların yanı sıra günün büyük bir bölümünü bu mekânlarda geçirmekte olan AVM çalışanlarında bu durum daha önemli bir hâl almaktadır. İnsanların fizyolojik ve psikolojik dengesinde önemli rol oynayan günışığından yeterince faydalanamayan bu kişiler ciddi sağlık 
sorunları ile karşılaşabilmektedir. Çalışma kapsamında öncelikle yapılarda konfor koşullarına ilişkin literatür araştırılmıştır. Örneklem olarak Edirne kent merkezinde bulunan bir AVM seçilerek bu AVM'nin tasarım özellikleri ve yapısal nitelikleri belirtilmiştir. Anket uygulanacak katılımcı grubu olarak AVM yapılarının uzun süreli kullanıcıları olan AVM çalışanları ele alınmıştır. Uygulanan anket ile elde edilen sonuçlar grafik anlatımlarla ifade edilerek istatistiksel analizler yardımıyla değerlendirilmiştir.

\section{II. ÖNCEKİ CALISMALAR}

Alışveriş merkezlerinde konfor koşullarının kullanıcıya etkisi ile ilgili çalışmalara bakıldığında; Shang vd., Çin'de dört farklı AVM de 1sıl konfor ve iç hava kalitesini ölçüm ve anket sonuçlarına göre değerlendirdikleri çalışmalarında, Formaldehit ve uçucu organik bileşik konsantrasyonlarına dikkat çekerek özellikle çalışanlarda hasta bina sendromu belirtilerinin görülme olasılığına vurgu yapmışlardır [37]. Chun ve Tamura, AVM yapılarının kullanıcılarının psikolojik durumu üzerindeki etkilerini, Bloch vd. AVM'lerdeki ortam kaynaklı tüketici davranışlarını araştırmışlardır [38-39]. Li vd. Hong Kong'da bulunan sekiz farklı AVM'de iç hava kirleticilerinin analizini yapmışlardır. Çoğunlukla hava kalitesinin kullanıcı yoğunluğuna bağlı olarak yüksek seviyelerde olduğunu ve AVM yapısının kent içerisindeki konumuna, mağazalarda dekoratif amaçla kullanılmış olan preslenmiş ahşap vb. bitiş malzemelerine ve satış ürünlerinin kirlilik oranları üzerindeki etkisini vurgulamışlardır [40]. Zoroğlu ve Gedik iki farklı AVM yapısının genel kullanım alanlarında ve mağazalarda ölçüme dayalı olarak çalışmışlardır. Bu çalışmada kullanıcı yoğunluğuna göre değişen bir iklimlendirme sisteminde 1sıl konfor parametrelerini ve Fanger modeli PMV-PPD endeksinde kullanıcı memnuniyetini değerlendirmişlerdir [14]. Elyiğit ve Ekinci, sekiz farklı AVM yapısının genel kullanım alanlarında kış koşullarında ölçüme dayalı yaptıkları çalışmada bağı nemin arttırılması, partikül madde miktarının azaltılması ve gürültü düzeyinin azaltılması konusunda önerilerde bulunmuştur [41]. Sezer vd. Bursa'da yer alan yedi alışveriş̧ merkezinde kullanıcı memnuniyetinin konfor koşulları açısından değerlendirilmesi amacıyla ankete dayalı bir çalışma yürütmüşlerdir [42]. Ayrıca literatürde 1sıl konfor, enerji korunumu ve tüketimi [43]; İç hava kalitesi [41]; İşitsel konfor [44-47] ve görsel konfor parametrelerinin farklı işleve sahip yapı örneklerinde ölçüme veya ankete dayalı pek çok araştırma bulunmaktadır [48-50]. Ancak özellikle gününün önemli bir kısmını bu yapılarda geçiren alışveriş merkezi çalışanları için konfor değerlendirmesini ele alan bir çalışmaya rastlanılamamıştır.

\section{MATERYAL METOT}

\section{A. ÖRNEKLEM ALINAN AVM YAPISININ ÖZELLİKLERİ}

Bu çalışma kapsamında Edirne İl merkezinde $96.188 \mathrm{~m}^{2}$ kapalı alana sahip Uluslararası Alışveriş Merkezleri Konseyi ICSC standartları sinıflandırılmasına göre, süper bölgesel kapalı AVM sınıfına giren lineer plan tipine sahip bir AVM incelenmiştir [51]. Çalışma kapsamında örnek olarak seçilen AVM binas1 Edirne İl merkezinde yer almaktadır. AVM bir uluslararas1 aks olan D100 Karayolu üzerinde, tarihi şehir merkezine $2 \mathrm{~km}$ uzaklıkta bulunmaktadır. Yapı lineer plan tipinde planlanmıştır. Uzun kenarı Kuzeydoğu (KD)-Güneybatı (GB) yönüne paralel şekilde konumlandırılmıştır (Şekil 1).2017 yılında kullanıma açılan AVM'de 125 mağaza, kafeterya ve restoranlar, süpermarket, sinema salonu, bar, çocuk oyun merkezi vb. işlevlere sahip mağazalar ve 1200 araç kapasiteli otopark yer almaktadır. Yap 3 otopark katı olmak üzere 4 bodrum kat, zemin kat ve 2 normal kattan oluşmaktadır. $21.000 \mathrm{~m}^{2}$ 'lik arsa alanı üzerine kurulmuş AVM'nin toplam inşaat alanı $100.868 \mathrm{~m}^{2}$ 'dir. 


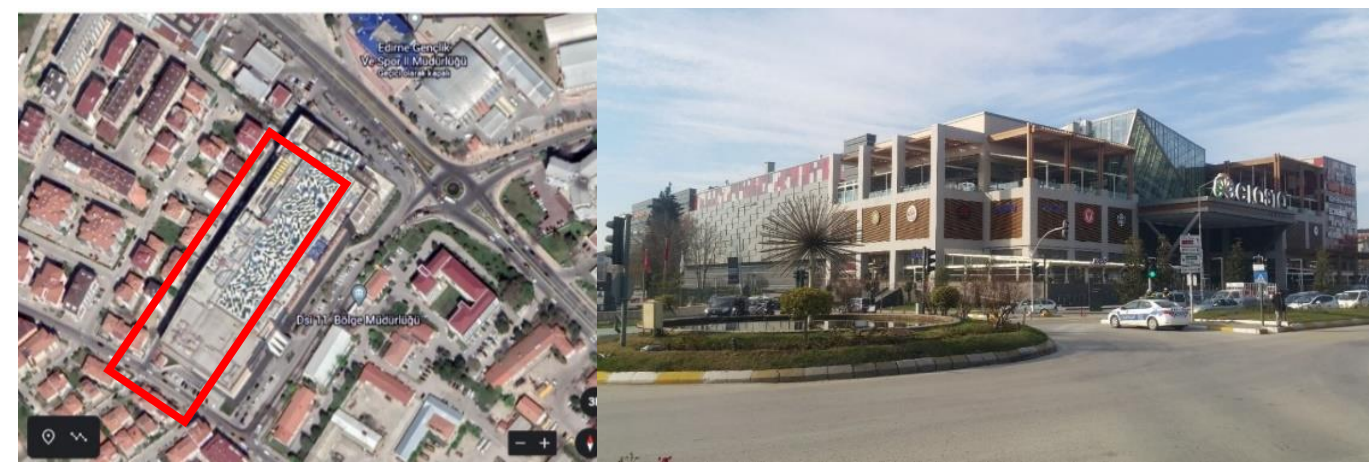

(a)

(b)

Şekil 1.(a)Alışveriş merkezi yakın çevresi ve (b) AVM Doğu perspektifi.

Gün 1şığından yararlanabilmek için atrium kullanılmıştır. Cephede seramik levha kaplama altına $8 \mathrm{~cm}$ 1S1 yalıtımı uygulanmıştır. Isıtma sistemi olarak merkezi iklimlendirme sistemi bulunmaktadır. AVM iç mekân malzemeleri renk seçiminde genellikle krem rengi, beyaz gibi açık renkler seçilmiştir [52]. Tablo 1 'de AVM'ye ait plan ve kesit krokileri yer almaktadır.

Tablo 1.AVM plan ve kesit krokileri.
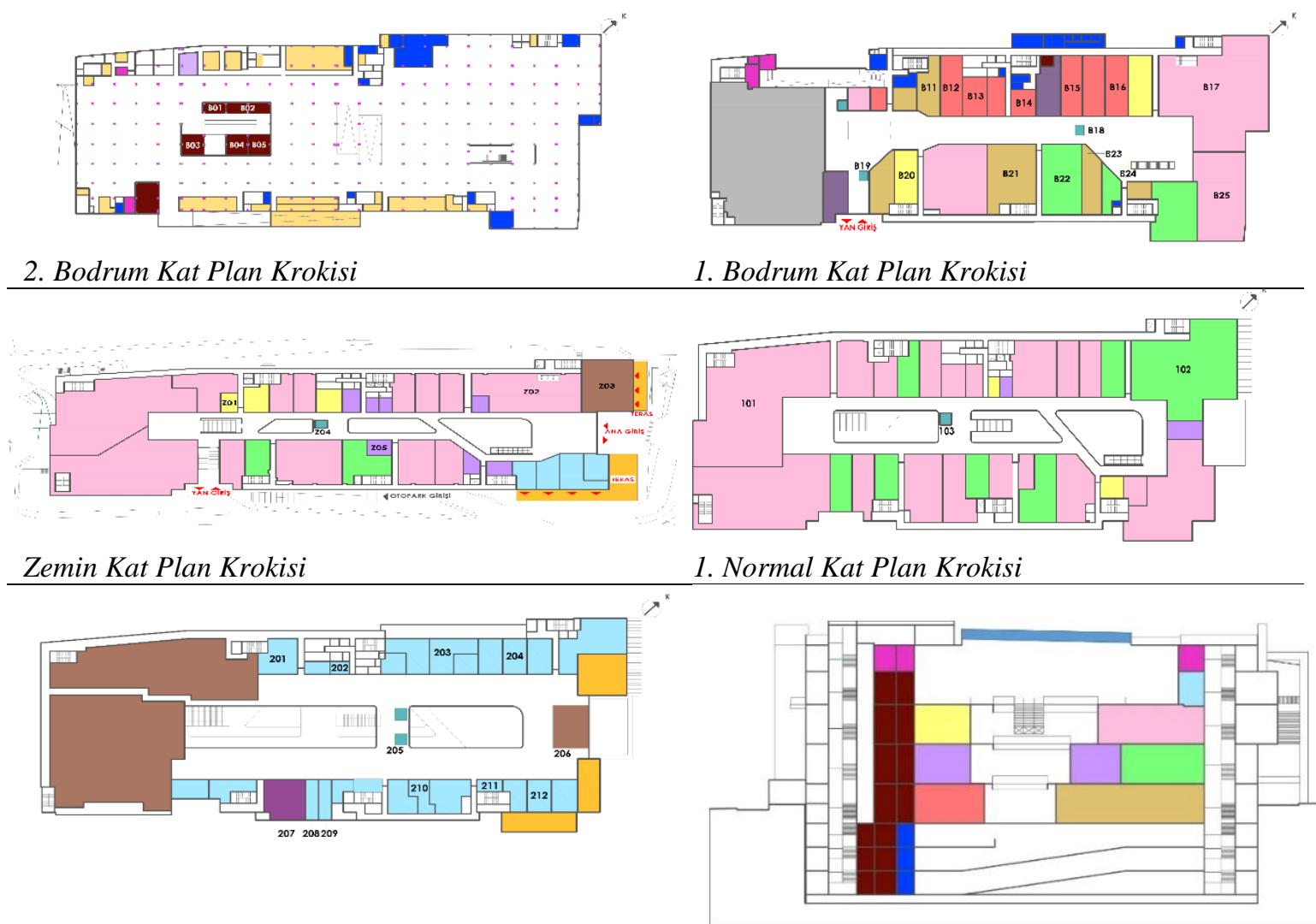

2. Normal Kat Plan Krokisi

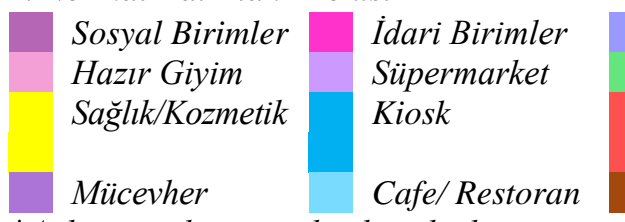

*Anket uygulanan mekanlara kod numarası verilmiştir.
Kesit Krokisi
Depo Birimleri Ayakkabı/Çanta Elektronik Ĕ̆lence
ilmiştir.

Teknik Birimler
Oyuncak
Hizmet
Birimleri

Diğer

Dekorasyon Kitap/Kirtasiye 


\section{B. ANKET UYGULAMASI}

Bu çalışmada araştırma evrenini, seçilmiş AVM'de çalışan kişiler oluşturmaktadır. AVM'de çalışan kişi sayısı ortalama 500 olup, bayramlar ve yılbaşı dönemi gibi alışveriş yoğunluğunun arttığı özel dönemlerde 600'e kadar çıkabilmektedir. Çalışmada araştırma evreninin tamamına ulaşmak mümkün olmadığından, araştırma evrenini temsil edecek özelliklere sahip daha az sayıda bir örneklem grubu seçilmiştir. Bu seçim işlemi yapılırken, bilimsel çalışmalarda kabul edilebilir örneklem büyüklügünü saptamak amacıyla Altunışık vd. tarafından evren büyüklükleri için belirlenmiş örneklem değerleri çizelgesinden yararlanılmıştır. Maksimum 600 kişilik bir çalışma evreni için minimum 234 kişiye anket uygulanması gerektiği tespit edilmiştir. Bu çalışmada 240 kişiye anket uygulanarak örneklemi temsil edecek yeterli sayıya ulaşılmıştır [53]. Anket çalışması Trakya Üniversitesi Sosyal ve Beşeri Bilimler Araştırmaları Etik Kurulunun 24.04.2019 tarih ve 2019.04.14 numaralı kararı ile onay alınarak uygulanmıştır. Anketler Nisan-Mayıs 2019 tarihlerinde gerçekleştirilmiştir.

Örnekleme yöntemleri; tesadüfi ve tesadüfi olmayan olarak ikiye ayrılmaktadır. Tesadüfi örneklemenin basit tesadüfi, katmanlı rastgele, küme örnekleme ve sistemli rastgele örnekleme olmak üzere 4 başlığı vardır [53-55]. Bu çalışmada örneklemenin evreni doğru bir şekilde temsil edebilmesi amacıyla mekân işlevleri, mağaza konumları, 1sıl konfor, iç hava kalitesi, görsel konfor ve işitsel konfor farkl11ıkları oluşabilecek sayıda farklı mağazadan örneklem alınarak basit tesadüfi örnekleme yöntemi kullanılmıştır. Ankete katılım gönüllülük esasıyla toplamda 39 birimde uygulanmış olup, sinema salonu, kapalı eğlence alanı ve süpermarkette ankete katılımı reddetmeleri nedeni ile örneklem alınamamıştır.

Anket formu hazırlanırken literatürde konfor değerlendirmesi amacıyla yapılan çalışmalar incelenmiş ve teorik bilgilerin 1şığında anket formu özgün olarak tasarlanmıştır. Dört bölümden oluşan anketin 1 . bölümünde kullanıcı bilgileri sorgulanmış katılımcıların yaş, cinsiyet, hastalık durumları vb. özellikleri araştırılmıştır. Daha sonraki bölümde, çalışılan ortamın fiziksel özellikleri ile ilgili bilgi alınmasını sağlayacak çalışılan kategori, çalışılan kat, çalışma saatleri, çalışılan ortamda bulunan kişi sayısı soruları yer almaktadır. 3. bölümde kişinin çalıştığı ortamda, 1sıl konfor, iç hava kalitesi, görsel ve işitsel konfor durumunu değerlendirmeye imkân tanıyan sorular ve son bölümde ise çalışma ortamında çalışanın sağlığı üzerine etkilerini değerlendirmek amaçlı literatürden elde edilen konforsuzluk kaynaklı sağlık belirtilerinin görülme sıklığı ile ilgili hazırlanmış sorular bulunmaktadır [5,14,24, 37-39,41-42,48-50]. Anket ölçeği 3'lü ve 5'li likert olarak uygulanmıştır.

\section{BULGULAR VE TARTIŞMA}

Güvenilirlik analizi, ölçmede kullanılan testlerin, anketlerin veya ölçeklerin güvenilirlik düzeylerini anlayabilmek için yaratılmış bir istatistiksel hesaplama metodudur. Güvenilirlik düzeyi az olan bir ölçmenin bilimsel bir değeri yoktur. Ancak güvenilirlik düzeyinin çok fazla çıkması da elde edilmiş ölçmenin hedefe uygunluğunun kesin bir göstergesi olduğu da düşünülmemelidir. Çalışmanın Güvenilirliği, gerekli bir koşuldur ancak yeterli bir koşul değildir [56].Likert tipindeki ölçeklerde, ölçeğin güvenilirliği belli bir matematiksel formülle hesaplanan alfa $(\alpha)$ katsayısı ile tespit edilir. $\mathrm{Bu}$ katsayının 1'e yakın bir değer çıkması ölçeğin güvenilirliğinin yüksek seviyede olduğunu göstermektedir. $\mathrm{Bu}$ katsayının düşük bir değer çıkmasını sağlayan sorular analizden çıkarılarak güvenilirlik seviyesi arttırılabilir. Eğer $\alpha$ değeri 0 ile 0,40 arasında çıkmışsa bu ölçeğin güvenilir olmadığını ifade eder. 0,40 ile 0,60 arasında çıkmışsa ölçeğin güvenilirliği düşük seviyededir. 0,60 ile 0,80 arasında ise ölçeğin güvenilirliği iyi seviyededir. 0,80 ile 1 arasında çıkmışsa ölçek yüksek seviyede güvenilirdir denir [56]. Çalışmada yer alan likert tipindeki soruların güvenilirliğini ölçmek için Cronbach Alfa Katsayısı hesaplanmıştır. İstatistiksel analizleri yapabilmek için araştırmacılar tarafından sıklıkla kullanılan SPSS 27 paket programı ile yapılan hesaplama sonucu konfor koşulları ile ilgili soruların Cronbach Alfa değeri 0,813 olarak hesaplanmıştır. Bu değer soruların ölçme düzeyinin yüksek seviyede güvenilir olduğunu göstermiştir.

Çalışmada yer alan konfor koşulları ile ilgili soruların geçerliği, Kaiser-Meyer-Olkin (KMO) örneklem yeterliliği ölçütü ile değerlendirilmiş ve KMO değeri 0,703 olarak hesaplanmıştır. Seçer [57], KMO değeri, 0,50'nin altında ise kabul edilemez, 0,50-0,60 değerleri arasında ise zayıf, 0,60-0,70 aralığında 
ise orta, $0,70-0,80$ aralığında ise iyi, 0,80-0,90 aralığında ise çok iyi, 0,90 'dan büyük ise mükemmel örneklem manasına gelmekte olduğunu belirtmiştir. Dolayısıyla, çalışmada yer alan konfor koşulları ile ilgili soruların geçerliğinin iyi seviyede olduğu görülmüştür. Dört bölümden oluşan anketin ilk bölümünde demografik özellikler değerlendirilmiştir. Elde edilen sayısal veriler incelendiğinde ankete katılan AVM çalışanlarının \%47,5'i kadın, \%52,5'i erkek olup yaklaşı \% \% 8 ' inin genç yaş kategorisinde (18-32) yer aldığı, öğrenim durumlarının ise \%39 lise, \%30 ön lisans, \%29 lisans mezunu oldukları, \%60'ının bekâr olduğu ve \%35'inin sigara kullandığı tespit edilmiştir. Anketin 2. bölümünde çalışma ortamının fiziksel koşulları, 3. bölümünde ise konfor beklentileri sorgulanmıştır. Bu bölüm ile ilgili bulgular konfor beklentileri ve sağlık üzerindeki etkileri ile değerlendirilmiştir.

Ankette yer alan cinsiyet, medeni hal, kronik veya hormonal hastalık, bağımsız değișkenlerinin, katılımcıların konfor koşullarından memnuniyeti üzerinde etkisi olup olmadığını araştırmak için MannWhitney U testi kullanılmıştır. Parametrik olmayan bu test, normal dağılım varsayımının gerçekleşmemesi durumunda, bağımsız iki grup arasında, istatistiksel olarak anlamlı farklılıkların varlığını araştırmak için kullanılmaktadır [58]. Analizler $\mathrm{p}=0,05$ anlamlılık düzeyinde gerçekleştirilmiştir. Analiz sonuçları Tablo 2'de verilmiştir. Elde edilen istatistiksel bulgulara göre; Tablo 2'deki anlamlılık düzeyleri incelendiğinde; " $\mathrm{p}<0,05$ " koşulunu sağlayan iki adet değer olduğu görülmektedir. Ayrıca, katılımcıların Medeni Durumu ile Konfor Koşullarından memnuniyet durumu arasında istatistiksel olarak anlamlı bir ilişki olup olmadığı yine Mann-Whitney U testi uygulanarak incelenmiştir. Evli ve bekar katılımcılar arasında çalıştıkları ortamdaki rahatsız edici koku farkındalığı açısından medeni duruma dayalı istatistiksel olarak anlamlı bir farkl11ık olduğu (sig. $=0,019)$ ve çalıştıkları ortamdaki iç kaynaklı gürülttü varlığı açısından anlamlı bir farklı1ık olduğu (sig. $=0,009$ )görülmüştür. Konfor ile ilgili diğer bağımlı değişkenlerde medeni duruma bağlı anlamlı farklılık bulunmamıştır. Yaş değişkeni ile konfor koşulları arasında ilişki Kruskal-Wallis testi ile değerlendirilmiş ancak istatistiksel olarak anlamlı bir farklılığa rastlanmamıştır. Katılımcıların hormonal hastalıklarının varlığına göre konfor koşullarından memnuniyet durumunun incelenmesine ilişkin Mann-Whitney U test sonuçlarına bakıldığında hormonal hastalığı olan veya olmayan katılımcılar arasında çalıştıkları ortamdaki gürültü düzeyinden rahatsız olma açısından hormonal hastalığın varlığına dayalı istatistiksel olarak anlamlı bir farklılık (sig. $=0,033)$ vardır. Diğer bağımlı konfor değişkenlerinde anlamlı farklılık bulunmamıştır. Katılımcıların kronik hastalıklarının varlığına göre konfor koşullarından memnuniyet durumu incelendiğinde ise sadece çalıştıkları ortamdaki iç kaynaklı gürültü varlığı açısından anlamlı farklılık (sig. $=0,018)$ görülmüsşür.

Tablo 2.Katılımcıların cinsiyetlerine göre konfor koşullarından memnuniyet durumunun incelenmesine ilişkin Mann-Whitney U test sonuçları

\begin{tabular}{|c|c|c|c|c|}
\hline \multicolumn{2}{|c|}{ Değişkenler } & \multirow{2}{*}{$\begin{array}{l}\text { Anlamlılık } \\
\text { Düzeyi }\end{array}$} & \multirow{2}{*}{$\begin{array}{l}\text { Kadın ve erkek katılımcılar arasında } \\
\text { calıștıkları ortamdaki .... açısından }\end{array}$} & \multirow{2}{*}{$\begin{array}{l}\text { Cinsiyete dayalı, } \\
\text { istatistiksel olarak anlamlı } \\
\text { bir farklılık }\end{array}$} \\
\hline Bağımsız & Bağımlı & & & \\
\hline \multirow{13}{*}{ 䆓 } & Konfor 1 & 0,553 & $\begin{array}{l}\text { Yaz mevsiminde ortam sicakliğının } \\
\text { memnuniyeti }\end{array}$ & Yoktur \\
\hline & Konfor 2 & 0,797 & $\begin{array}{l}\text { Kış mevsiminde ortam slcaklığının } \\
\text { memnuniyeti }\end{array}$ & Yoktur \\
\hline & Konfor 3 & 0,802 & Nemlilik durumundan memnuniyeti & Yoktur \\
\hline & Konfor 4 & 0,828 & Temiz hava miktarından memnuniyet & Yoktur \\
\hline & Konfor 5 & 0,965 & Havadaki toz miktarını değgerlendirme & Yoktur \\
\hline & Konfor 6 & 0,422 & Rahatsız edici koku farkındalı̆̆ & Yoktur \\
\hline & Konfor 7 & $\mathbf{0 , 0 1 1}$ & Doğal ışık alıp almaması & Vardır \\
\hline & Konfor 8 & 0,681 & $\begin{array}{l}\text { Doğal aydınlatmasını yeterli bulup } \\
\text { bulmama }\end{array}$ & Yoktur \\
\hline & Konfor 9 & 0,745 & $\begin{array}{l}\text { Çalışma günlerinde gün ışı̆̆ından } \\
\text { faydalanma süreleri }\end{array}$ & Yoktur \\
\hline & Konfor 10 & 0,462 & Yapay aydınlatma düzeyinden memnuniyet & Yoktur \\
\hline & Konfor 11 & 0,040 & Gürültü̈ düzeyini tanımlama & Vardır \\
\hline & Konfor 12 & 0,483 & Dış kaynaklı gürültüu varlığı & Yoktur \\
\hline & Konfor 13 & 0,082 & 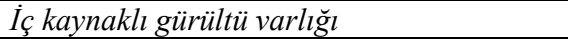 & Yoktur \\
\hline
\end{tabular}

Anketten elde edilen sayısal veriler incelendiğinde katılımcıların \%56,7'sinin normal giysi ile 1sıl konfor koşullarından memnun olduğu tespit edilmiştir (Şekil 2). Mevsimlere göre ortam sicaklı̆̆ sorgulandığında ise Şekil 3'te görüldüğü üzere ortam sıcaklığından kış mevsiminde \%82,1 oranında 
memnuniyet duyulurken, yaz mevsiminde \%80,4 oranında memnuniyet duyulmaktadır. Nemlilik durumu ve temiz havayı da kullanıcıların büyük çoğunluğu uygun bulmaktadır (Şekil 4).

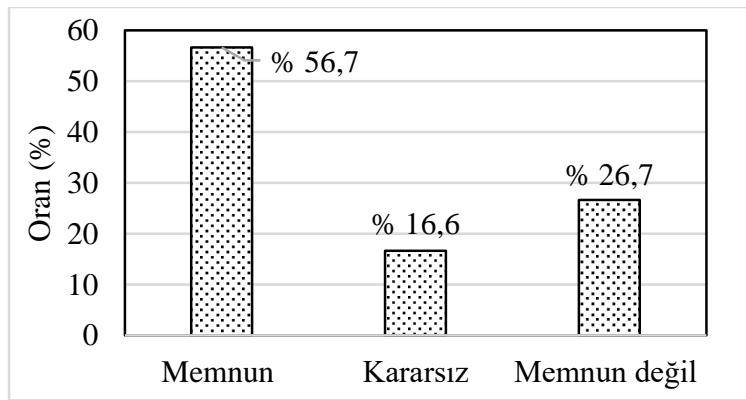

Şekil 2.Isıl konfor memnuniyet durumu.

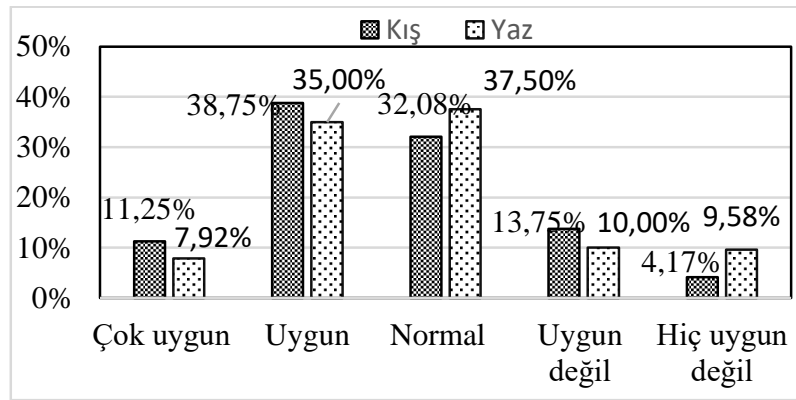

Şekil 3. Yaz ve kışşartlarında ortam sıcaklı̆̆ memnuniyet durumu.

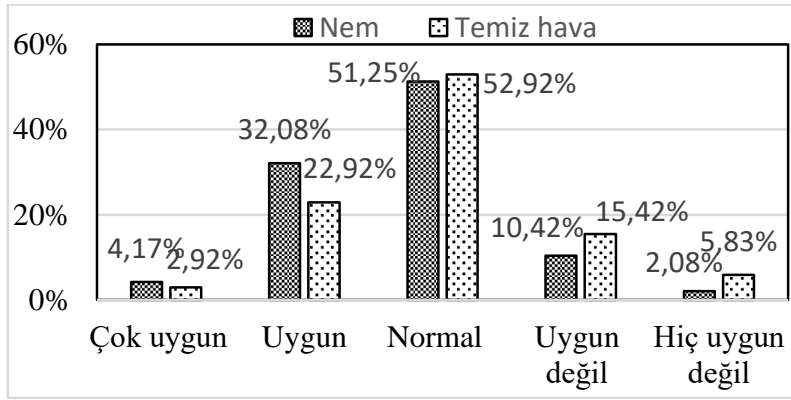

Şekil 4. Ortamın nemlilik durumu ve temiz hava miktarı değerlendirmesi.

İç hava kalitesi ile ilgili olarak; çalışılan ortamdaki temiz hava miktarından katılımcıların büyük çoğunluğu memnundur. AVM çalışanlarının \%6,7'si her gün çalışma ortamında toz hissederken, \%10'u çok sık, \%20'si sık sık toz hissetmektedir. Çalışma ortamında toz ve koku hissetme sıklığı yüzdeleri Şekil 5'de sunulmaktadır. Anket katılımcılarından \%9,6'sı her gün çalışma ortamında rahatsız edici koku bulunduğunu belirtilirken \%7,1'i çok sık, \%7,1'i de sık sık çalışma ortamında rahatsız edici koku bulunduğunu söylemektedir.

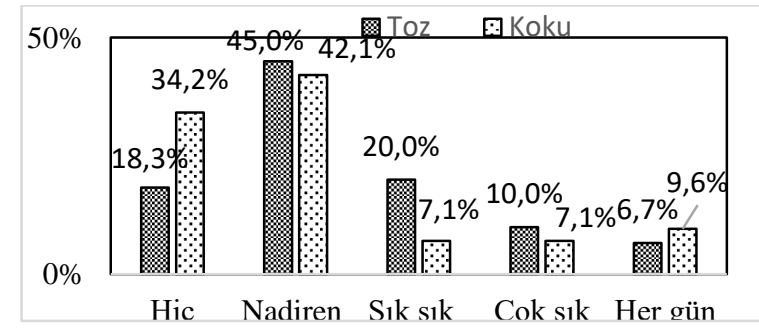

Şekil 5. Toz ve rahatsız edici koku hissetme. 
Kikare bağımsızlık testleri, iki kategorik değişkenin arasında bir ilişki olup olmadığını analiz etmek için kullanılan non-parametrik bir testtir. Bu test 2x2'lik veya daha büyük boyutlu kontenjans tablolarındaki değişkenlerin gözlenen ve beklenen frekanslarını karşılaştırarak iki değişken arasında bağımsızlık olup olmadığını araştırmak için kullanılır [59]. Tablo 3 incelendiğinde Sigara kullanımı değişkeni ile kullanıcıların çalışma ortamındaki rahatsız edici kokunun varlığı değişkeni arasında $\mathrm{p}=0,05$ anlamlılık düzeyinde istatistiksel olarak anlamlı bir ilişki olduğu görülmektedir $(\mathrm{p}=0,044<0,05)$. Rahatsız edici kokunun "her gün" var olduğunu söyleyen katılımcıların yaklaşık \%55,4'ünün sigara kullanmadığı, buna karşın \%44'6'sının sigara kullanmakta olduğu görülmektedir. Rahatsız edici kokunun "çok sık" var olduğunu söyleyen katılımcıların yaklaşık \%74'ünün sigara kullanmadığı, buna karşın \%26'sının sigara kullanmakta olduğu görülmektedir. Benzer oranların diğer kategorilerde de var olduğu görüldüğünden, sigara kullanmayanların kullananlara kıyasla rahatsız edici koku konusunda daha hassas olduğu çıkarımı yapılabilir.

Tablo 3. Sigara kullanımı değişkeni ile katılımcıların çalışma ortamındaki rahatsız edici kokunun varlı̆̆ı değişkeni arasındaki Ki-kare analizi tablosu

\section{Sigara kullanımı}

\begin{tabular}{|c|c|c|c|c|c|}
\hline & & & Kullanmiyor & Kullanıyor & Toplam \\
\hline \multirow{15}{*}{ 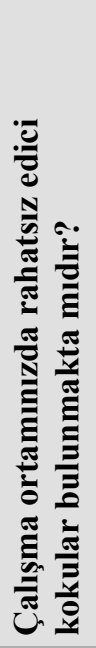 } & \multirow[t]{3}{*}{ Hiç } & Frekans & 12 & 11 & 23 \\
\hline & & Satır yüzde & $52,2 \%$ & $47,8 \%$ & $100,0 \%$ \\
\hline & & Sütun yüzde & $7,6 \%$ & $13,3 \%$ & $9,6 \%$ \\
\hline & \multirow[t]{3}{*}{ Nadiren } & Frekans & 13 & 4 & 17 \\
\hline & & Satır yüzde & $76,5 \%$ & $23,5 \%$ & $100,0 \%$ \\
\hline & & Sütun yüzde & $8,3 \%$ & $4,8 \%$ & $7,1 \%$ \\
\hline & \multirow[t]{3}{*}{ Sık sık } & Frekans & 12 & 5 & 17 \\
\hline & & Satır yüzde & $70,6 \%$ & $29,4 \%$ & $100,0 \%$ \\
\hline & & Sütun yüzde & $7,6 \%$ & $6,0 \%$ & $7,1 \%$ \\
\hline & \multirow[t]{3}{*}{ Çok sık } & Frekans & 74 & 26 & 100 \\
\hline & & Satır yüzde & $74,0 \%$ & $26,0 \%$ & $100,0 \%$ \\
\hline & & Sütun yüzde & $47,1 \%$ & $31,3 \%$ & $41,7 \%$ \\
\hline & \multirow[t]{3}{*}{ Her gün } & Frekans & 46 & 37 & 83 \\
\hline & & Satır yüzde & $55,4 \%$ & $44,6 \%$ & $100,0 \%$ \\
\hline & & Sütun yüzde & $29,3 \%$ & $44,6 \%$ & $34,6 \%$ \\
\hline \multirow{3}{*}{\multicolumn{2}{|c|}{ Toplam }} & Frekans & 157 & 83 & 240 \\
\hline & & Satır yüzde & $65,4 \%$ & $34,6 \%$ & $100,0 \%$ \\
\hline & & Sütun yüzde & $100,0 \%$ & $100,0 \%$ & $100,0 \%$ \\
\hline
\end{tabular}

0 hücre (\% 0) beklenen değer 5 'den küçük değildir. En küçük beklenen değer $5,88^{\prime}$ dir. Ki-kare test istatistiği $\chi 2=9,824$ ve Anlamlılık Düzeyi $(p)=0,044$

Kruskal-Wallis testi, tek yönlü varyans analizinin varsayımlarından birinin sağlanmadığı durumda tek yönlü varyans analizine karşl1ık gelen parametrik olmayan bir testtir [60]. Tablo 4'te paylaşılan Kruksal Wallis test sonuçlarından da görüleceği üzere, AVM genelinde çalışanların toz ve koku hissetme durumunun fonksiyona (Mağaza türüne) bağlı olarak istatistiksel olarak anlamlı farklılık gösterdiği tespit edilmiştir. 
Tablo 4. Katılımcıların çalıştıkları çalıştıkları kategoriye göre konfor koşullarından memnuniyet durumunun incelenmesine ilişkin Kruskal-Wallis test sonuçları

\begin{tabular}{|c|c|c|c|c|c|c|}
\hline \multirow{12}{*}{ 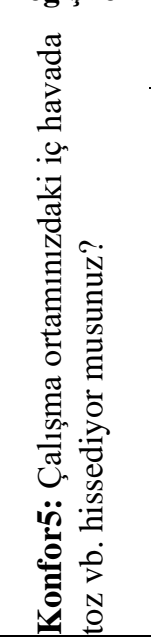 } & Bağımsız Değişken & & $\begin{array}{c}\text { Ortalama } \\
\text { Sura }\end{array}$ & $\gamma^{2}$ & Sig. & Acıklama \\
\hline & Hazır giyim & $\frac{N}{76}$ & $\begin{array}{c}\text { Sira } \\
110.08\end{array}$ & \multirow{11}{*}{43,930} & \multirow{11}{*}{0,000} & \multirow{11}{*}{$\begin{array}{l}\text { Katılımcıların çalıştıkları } \\
\text { kategoriye göre çalıştıkları } \\
\text { ortamdaki iç havadaki toz } \\
\text { miktarını değerlendirme } \\
\text { açıısından çalışılan kategoriye } \\
\text { dayalı istatistiksel olarak } \\
\text { anlamlı bir farklılık vardır. }\end{array}$} \\
\hline & Ayakkabi/canta & 17 & 85,68 & & & \\
\hline & Mücevher/Aksesuar & 3 & 142,50 & & & \\
\hline & Sağlık/Kozmetik & 9 & 167,61 & & & \\
\hline & Dekorasyon/Ev tekstili & 7 & 76,50 & & & \\
\hline & Elektronik & 23 & 77,54 & & & \\
\hline & Cafe/Restaurant & 54 & 150,39 & & & \\
\hline & Kitap/Kırtasiye & 2 & 18,50 & & & \\
\hline & Eğlence & 19 & 142,18 & & & \\
\hline & $\begin{array}{l}\text { Hizmet (Kuru temizleme, } \\
\text { Terzi, Tobacco, Oto yıkama, } \\
\text { Banka vs.) }\end{array}$ & 23 & 134,76 & & & \\
\hline & Kiosk & 7 & 126,21 & & & \\
\hline \multirow{12}{*}{ 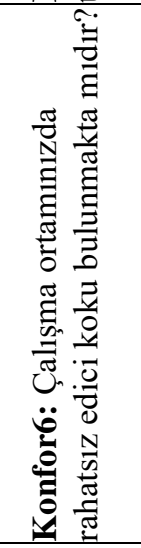 } & Hazır giyim & 76 & 152,91 & \multirow{12}{*}{74,948} & \multirow{12}{*}{0,000} & \multirow{12}{*}{$\begin{array}{l}\text { Katılımcıların çalıştıkları } \\
\text { kategoriye göre çalıştıkları } \\
\text { ortamdaki rahatsız edici koku } \\
\text { farkındalığı açısından çalışılan } \\
\text { kategoriye dayalı istatistiksel } \\
\text { olarak anlamlı bir farklılık } \\
\text { vardır. }\end{array}$} \\
\hline & Ayakkabı/çanta & 17 & 79,94 & & & \\
\hline & Mücevher/Aksesuar & 3 & 168,50 & & & \\
\hline & Sağlık/Kozmetik & 9 & 178,67 & & & \\
\hline & Dekorasyon/Ev tekstili & 7 & 106,36 & & & \\
\hline & Elektronik & 23 & 123,17 & & & \\
\hline & Cafe/Restaurant & 54 & 113,06 & & & \\
\hline & Kitap/Kırtasiye & 2 & 153,25 & & & \\
\hline & Eğlence & 19 & 107,89 & & & \\
\hline & Hizmet (Kuru temizleme, & & & & & \\
\hline & $\begin{array}{l}\text { Terzi, Tobacco, Oto yıkama, } \\
\text { Banka vs.) }\end{array}$ & 23 & 36,30 & & & \\
\hline & Kiosk & 7 & 135,93 & & & \\
\hline
\end{tabular}

Hazır giyim, elektronik, ayakkabı-çanta fonksiyonlarında toz hissedilme oranı diğer fonksiyonlara göre daha fazla olup, fonksiyona bağlı dağılım Şekil 8'de görülmektedir. Hizmet sektörü çalışma ortamında rahatsız edici kokunun en sık görüldügü fonksiyon olup, hizmet sektörüne ait çalışma alanlarının genelde bodrum katta yer almasından dolayı otoparktan gelen egzoz dumanına bağlı rahatsız edici koku bulunabileceği tahmin edilmektedir. Rahatsız edici kokuya sıkça rastlanılan diğer fonksiyonlar $\mathrm{kafe} /$ restoran ve ayakkabı/çanta ürünlerinin satıldığı çalışma ortamlarıdır. Bu alanlardaki rahatsız edici koku kaynakları, kafe ve restoranlarda yemek pişirme eylemi sırasında açığa çıkan kokular, ayakkabı ve çanta ürün guruplarının satıldığı ortamlarda ise bu ürünlerin üretimi sırasındaki yapıştırma gibi eylemlerdir.

Görsel konforla ilgili değerlendirmelerde, 'Çalıştığınız ortam doğal 1şık alıyor mu?' sorusuna AVM çalışanlarının \%64,6'sı hayır derken, \% 35,4'ünün evet dediği tespit edilmiştir. AVM Kapalı planlı olmasına rağmen, atriumlu olması şeffaf çatıdan günışı̆̆ının iç ortama aktarılması dolaylı olarak ve bazı kafeterya birimlerinin dış ortama açılan düşey pencerelerinin bulunması ise doğrudan günışığından yararlanılmasına imkân tanımaktadır. Çalışma ortamında doğal aydınlatmadan memnuniyet durumuna bakıldığında, katılımcıların \%50,8'i doğal aydınlatmayı uygun bulmamakta ya da hiç uygun bulmamaktadır ve bu değerler Şekil 6' da açıkça görülmektedir. 


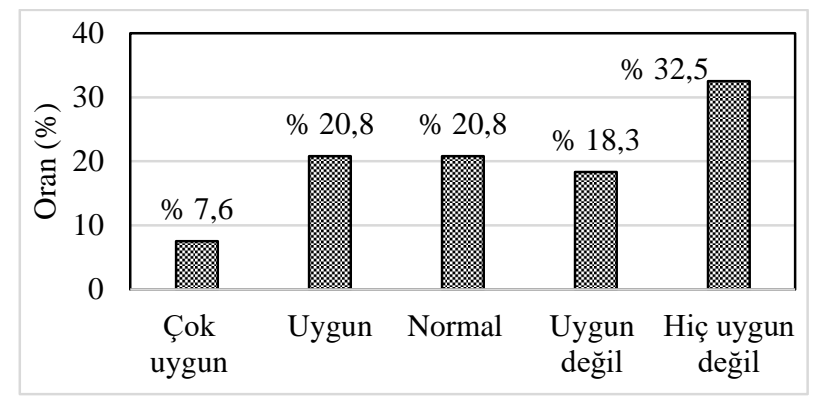

Şekil 6. Doğal aydınlatmadan duyulan memnuniyet.

Şekil 7'da çalışanların gün boyunca doğal ışıktan kaç saat faydalandıklarına bakıldığında, \%13,3'ünün çalışma günlerinde hiç doğal ışık almadıkları ve \%61,7 gibi önemli bir oranın ise sadece 1-3 saat doğal ışık aldıkları sonucu çıkmaktadır. Çalışma ortamında yapay ışık kaynakları ile sağlanmış aydınlatma düzeyleri Şekil 8'de belirtilmekte ve \%66,7'sinin aydınlığ yeterli bulduğu görülmektedir. Diğer kullanıcılar ise yetersiz ya da gereğinden fazla aydınlık olduğunu öne sürmektedir.

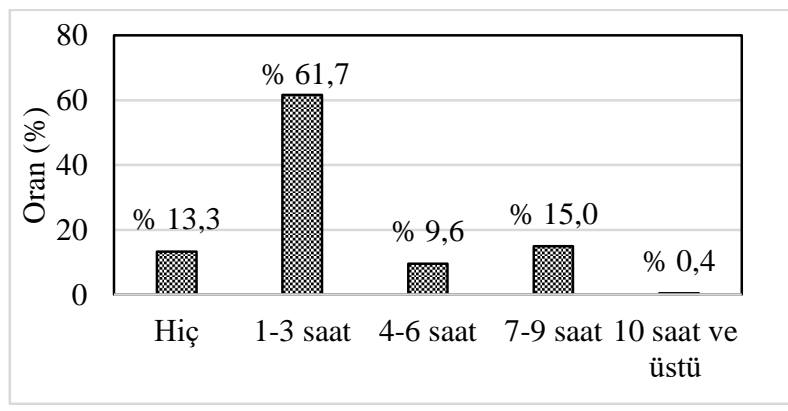

Şekil 7. Gün boyunca doğal lşıktan faydalanma miktarları.

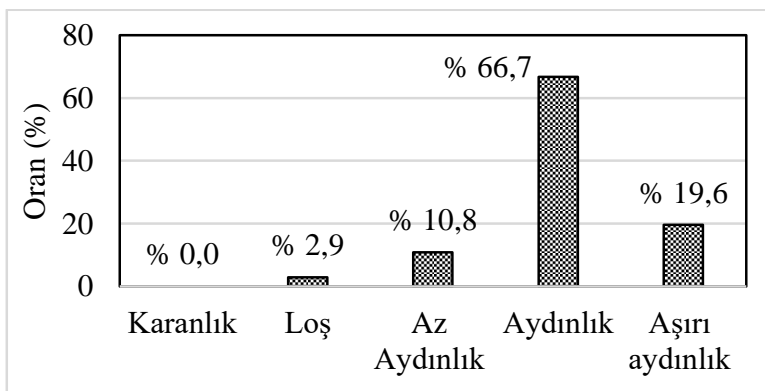

Şekil 8. Yapay ışık kaynakları ile sağlanmıs aydınlatma düzeyleri.

İşitsel konfor parametreleri değerlendirildiğinde; ankete katılan çalışanların \%54,2'sinin çalışma ortamını gürültülü, $\% 25,8$ 'inin ise aşırı gürültülü bulduğunu ifade etmiştir. Bu durum genellikle AVM çalışanlarının ortamın işitsel konfor düzeyinden memnun olmadığını göstermektedir (Şekil 9). Katılımcıların \%92,5'i çalışma ortamı kaynaklı gürültü olduğunu belirtirken \%20,8'i çalışma ortamına dış ortamdan gürültü geldiğini belirtmektedir (Şekil 10). 


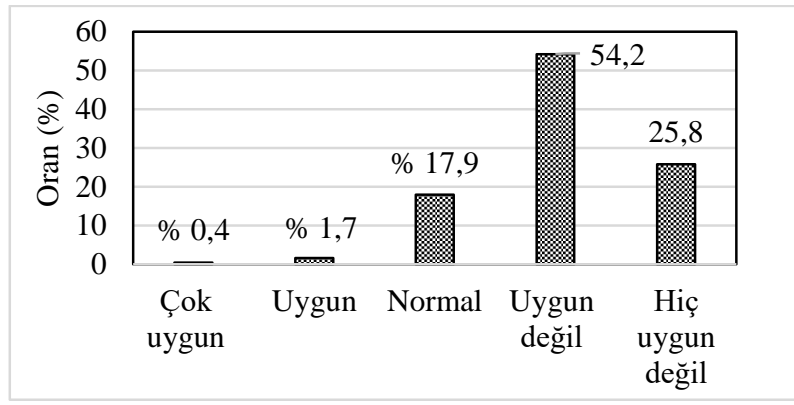

Şekil 9. Çallşllan ortamdaki gürültü memnuniyet düzeyleri.

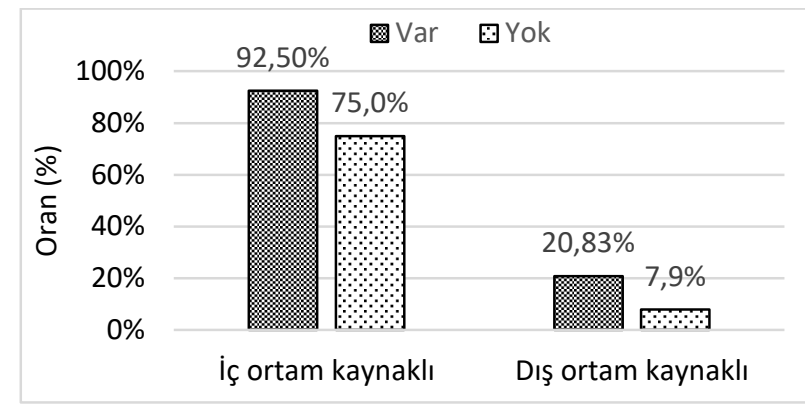

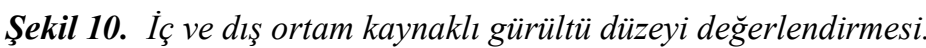

Dış ortamdan gelen gürültünün genellikle terası bulunan mahallerde görüldüğü tespit edilmiş ve en büyük etkeninin trafik gürültüsü olduğu belirtilmektedir. İç ortam kaynaklı gürültünün ise en önemli kaynaklarının insan sesi ve müzik sesi olduğu görülmektedir. Çalışma ortamında gürültü düzeyinin sesli ve aşırı sesli olduğunu belirtenlerin çalışma fonksiyonuna bağlı oranları Şekil 11'de görülmektedir.

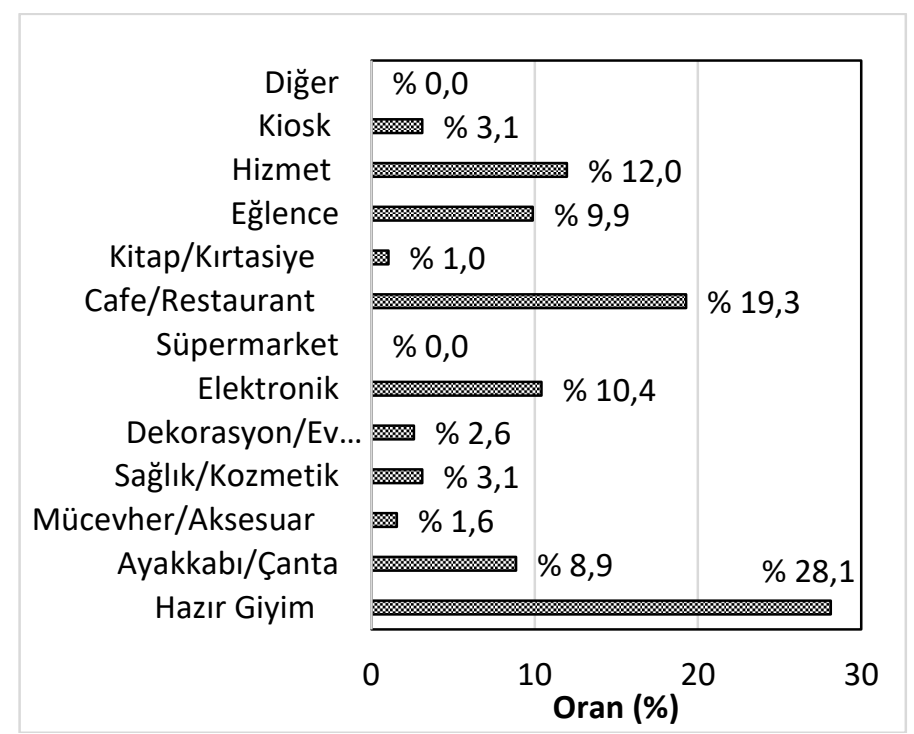

Şekil 11. Gürültü düzeyi yüksek olan mekânlar.

Katılımcıların çalıştıkları farklı katlara göre konfor koşullarından memnuniyet düzeyleri açısından istatistiksel olarak anlamlı bir farklılık yaratıp yaratmadığ ${ }_{1}$ Kruskal-Wallis testi ile $\mathrm{p}=0,05$ anlamlılık düzeyinde araştırılmıştır. Analiz sonuçları ve yorumları Tablo 5'te verilmiştir. 
Tablo 5. Katılımcıların çalıştıkları farklı katlara göre konfor koşullarından memnuniyet durumunun incelenmesine ilişkin Kruskal-Wallis test sonuçları

\begin{tabular}{|c|c|c|c|c|c|}
\hline Bağımlı Değişken & $\begin{array}{l}\text { Bağımsız } \\
\text { Değişken }\end{array}$ & $\mathbf{N}$ & $\chi^{2}$ & Sig. & Açıklama \\
\hline $\begin{array}{l}\text { Konfor 1: Yaz } \\
\text { mevsiminde çalıştığınız } \\
\text { ortamın sıcaklığını } \\
\text { nasıl değerlendirirsiniz? }\end{array}$ & $\begin{array}{c}\begin{array}{l}\text { Çalışılan } \\
\text { Kat }\end{array} \\
-2 \\
-1 \\
0 \\
1 \\
2 \\
\end{array}$ & $\begin{array}{l}24 \\
77 \\
59 \\
19 \\
61\end{array}$ & 80,238 & 0,000 & $\begin{array}{l}\text { Farklı katlarda çalışan katılımcılar } \\
\text { arasında yaz mevsiminde çalıştıkları } \\
\text { ortamın sıcaklığının memnuniyeti } \\
\text { açısından farklı katlarda çalışmaya } \\
\text { dayalı istatistiksel olarak anlamlı bir } \\
\text { farklılık vardır. }\end{array}$ \\
\hline $\begin{array}{l}\text { Konfor 2: Kış } \\
\text { mevsiminde çalıştığınız } \\
\text { ortamın sıcaklığını } \\
\text { nasıl değerlendirirsiniz? }\end{array}$ & $\begin{array}{l}-2 \\
-1 \\
0 \\
1 \\
2\end{array}$ & $\begin{array}{l}24 \\
77 \\
59 \\
19 \\
61\end{array}$ & 85,667 & 0,000 & $\begin{array}{l}\text { Farklı katlarda çalışan katılımcılar } \\
\text { arasında kış mevsiminde çalıştıkları } \\
\text { ortamın slcaklığının memnuniyeti } \\
\text { açısından farklı katlarda çalışmaya } \\
\text { dayalı istatistiksel olarak anlamlı bir } \\
\text { farklılık vardır. }\end{array}$ \\
\hline $\begin{array}{l}\text { Konfor3: Çalıştığınız } \\
\text { ortamdaki nemlilik } \\
\text { durumunu uygun } \\
\text { buluyor musunuz? }\end{array}$ & $\begin{array}{l}-2 \\
-1 \\
0 \\
1 \\
2\end{array}$ & $\begin{array}{l}24 \\
77 \\
59 \\
19 \\
61\end{array}$ & 42,092 & 0,000 & $\begin{array}{l}\text { Farklı katlarda çalışan katılımcılar } \\
\text { arasında çalıştıkları ortamın nemlilik } \\
\text { durumundan memnuniyeti açısından } \\
\text { farklı katlarda çalışmaya dayalı } \\
\text { istatistiksel olarak anlamlı bir farklılık } \\
\text { vardır. }\end{array}$ \\
\hline $\begin{array}{l}\text { Konfor 4: Çalıştığınız } \\
\text { ortamdaki temiz hava } \\
\text { miktarını nasıl } \\
\text { değerlendiriyorsunuz? }\end{array}$ & $\begin{array}{l}-2 \\
-1 \\
0 \\
1 \\
2\end{array}$ & $\begin{array}{l}24 \\
77 \\
59 \\
19 \\
61\end{array}$ & 13,636 & 0,009 & $\begin{array}{l}\text { Farklı katlarda çalışan katılımcılar } \\
\text { arasında çalıştıkları ortamdaki temiz } \\
\text { hava miktarından memnuniyet açısından } \\
\text { farklı katlarda çalışmaya dayalı } \\
\text { istatistiksel olarak anlamlı bir farklılık } \\
\text { vardır. }\end{array}$ \\
\hline $\begin{array}{l}\text { Konfor 5: Çalışma } \\
\text { ortamınızdaki iç havada } \\
\text { toz vb. hissediyor } \\
\text { musunuz? }\end{array}$ & $\begin{array}{r}-2 \\
-1 \\
0 \\
1 \\
2\end{array}$ & $\begin{array}{l}24 \\
77 \\
59 \\
19 \\
61\end{array}$ & 18,293 & 0,001 & $\begin{array}{l}\text { Farklı katlarda çalışan katılımcılar } \\
\text { arasında çalıştıkları ortamdaki iç } \\
\text { havadaki toz miktarını değerlendirme } \\
\text { açısından farklı katlarda çalışmaya } \\
\text { dayalı istatistiksel olarak anlamlı bir } \\
\text { farklılık vardır. }\end{array}$ \\
\hline $\begin{array}{l}\text { Konfor 6: Çalışma } \\
\text { ortamınızda rahatsız } \\
\text { edici koku bulunmakta } \\
\text { mıdır? }\end{array}$ & $\begin{array}{l}-2 \\
-1 \\
0 \\
1 \\
2\end{array}$ & $\begin{array}{l}24 \\
77 \\
59 \\
19 \\
61\end{array}$ & 53,284 & 0,000 & $\begin{array}{l}\text { Farklı katlarda çalışan katılımcılar } \\
\text { arasında çalıştıkları ortamdaki rahatsız } \\
\text { edici koku farkındalığı açısından farklı } \\
\text { katlarda çalışmaya dayalı istatistiksel } \\
\text { olarak anlamlı bir farklılık vardır. }\end{array}$ \\
\hline $\begin{array}{l}\text { Konfor 7: Çalıştığınız } \\
\text { ortam doğal ışık alıyor } \\
\text { mu? }\end{array}$ & $\begin{array}{l}-2 \\
-1 \\
0 \\
1 \\
2\end{array}$ & $\begin{array}{l}24 \\
77 \\
59 \\
19 \\
61\end{array}$ & 148,720 & 0,000 & $\begin{array}{l}\text { Farklı katlarda çalışan katılımcılar } \\
\text { arasında çalıştıkları ortamın doğal ışık } \\
\text { alıp almaması açısından farklı katlarda } \\
\text { çalışmaya dayalı istatistiksel olarak } \\
\text { anlamlı bir farklılık vardır. }\end{array}$ \\
\hline $\begin{array}{l}\text { Konfor 8: Çalıştığınız } \\
\text { ortamdaki doğal } \\
\text { aydınlatmayı yeterli } \\
\text { buluyor musunuz? }\end{array}$ & $\begin{array}{l}-2 \\
-1 \\
0 \\
1 \\
2\end{array}$ & $\begin{array}{l}24 \\
77 \\
59 \\
19 \\
61\end{array}$ & 49,502 & 0,000 & $\begin{array}{l}\text { Farklı katlarda çalışan katılımcılar } \\
\text { arasında çalıştıkları ortamdaki doğal } \\
\text { aydınlatmayı yeterli bulup bulmama } \\
\text { açısından farklı katlarda çalışmaya } \\
\text { dayalı istatistiksel olarak anlamlı bir } \\
\text { farklılık vardır. }\end{array}$ \\
\hline
\end{tabular}


Tablo 5. (devam) Katılımcıların çalıştıkları farklı katlara göre konfor koşullarından memnuniyet durumunun incelenmesine ilişkin Kruskal-Wallis test sonuçları

\begin{tabular}{|c|c|c|c|c|c|}
\hline $\begin{array}{l}\text { Konfor 9: Çalışma } \\
\text { günlerinizde, gün } \\
\text { boyunca gün 1şığından } \\
\text { kaç saat } \\
\text { faydalanıyorsunuz? }\end{array}$ & $\begin{array}{c}-2 \\
-1 \\
0 \\
1 \\
2\end{array}$ & $\begin{array}{l}24 \\
77 \\
59 \\
19 \\
61\end{array}$ & 52,458 & 0,000 & $\begin{array}{l}\text { Farklı katlarda çalışan katılımcılar } \\
\text { arasında çalışma günlerinde gün } \\
\text { lşı̆̆ından faydalanma süreleri açısından } \\
\text { farklı katlarda çalışmaya dayalı } \\
\text { istatistiksel olarak anlamlı bir farklılık } \\
\text { vardır. }\end{array}$ \\
\hline $\begin{array}{l}\text { Konfor 10: Çalışma } \\
\text { ortamınızda, yapay ışık } \\
\text { kaynakları ile } \\
\text { sağlanmış aydınlatma } \\
\text { düzeyini nassıl } \\
\text { değerlendiriyorsunuz? }\end{array}$ & $\begin{array}{c}-2 \\
-1 \\
0 \\
1 \\
2\end{array}$ & $\begin{array}{l}24 \\
77 \\
59 \\
19 \\
61\end{array}$ & 23,342 & 0,000 & $\begin{array}{l}\text { Farklı katlarda çalışan katılımcılar } \\
\text { arasında çalıştıkları ortamdaki yapay } \\
\text { aydınlatma düzeyinden memnuniyet } \\
\text { açısından farklı katlarda çalışmaya } \\
\text { dayalı istatistiksel olarak anlamlı bir } \\
\text { farklılık vardır. }\end{array}$ \\
\hline $\begin{array}{l}\text { Konfor 11: Çalıştığınız } \\
\text { ortamdaki gürültü } \\
\text { düzeyini tanımlayınız. }\end{array}$ & $\begin{array}{c}-2 \\
-1 \\
0 \\
1 \\
2\end{array}$ & $\begin{array}{l}24 \\
77 \\
59 \\
19 \\
61\end{array}$ & 22,247 & 0,000 & $\begin{array}{l}\text { Farklı katlarda çalışan katılımcılar } \\
\text { arasında çalıştıkları ortamdaki gürültü } \\
\text { düzeyini tanımlama açısından farklı } \\
\text { katlarda çalışmaya dayalı istatistiksel } \\
\text { olarak anlamlı bir farklılık vardır. }\end{array}$ \\
\hline $\begin{array}{l}\text { Konfor 12: Çalışma } \\
\text { ortamınıza diş } \\
\text { ortamdan gelen gürültü } \\
\text { var mı? }\end{array}$ & $\begin{array}{c}-2 \\
-1 \\
0 \\
1 \\
2\end{array}$ & $\begin{array}{l}24 \\
77 \\
59 \\
19 \\
61\end{array}$ & 38,663 & 0,000 & $\begin{array}{l}\text { Farklı katlarda çalışan katılımcılar } \\
\text { arasında çalıştıkları ortamdaki dış } \\
\text { kaynaklı gürültü varlığı açısından farklı } \\
\text { katlarda çalışmaya dayalı istatistiksel } \\
\text { olarak anlamlı bir farklılık vardır. }\end{array}$ \\
\hline $\begin{array}{l}\text { Konfor 13: Çalışma } \\
\text { ortamınızda iç ortam } \\
\text { kaynaklı gürültü var } \\
\text { mı? }\end{array}$ & $\begin{array}{c}-2 \\
-1 \\
0 \\
1 \\
2\end{array}$ & $\begin{array}{l}24 \\
77 \\
59 \\
19 \\
61\end{array}$ & 12,211 & 0,016 & $\begin{array}{l}\text { Farklı katlarda çalışan katılımcılar } \\
\text { arasında çalıştıkları ortamdaki iç } \\
\text { kaynaklı gürültü varlığı açısından farklı } \\
\text { katlarda çalışmaya dayalı istatistiksel } \\
\text { olarak anlamlı bir farklılık vardır. }\end{array}$ \\
\hline
\end{tabular}

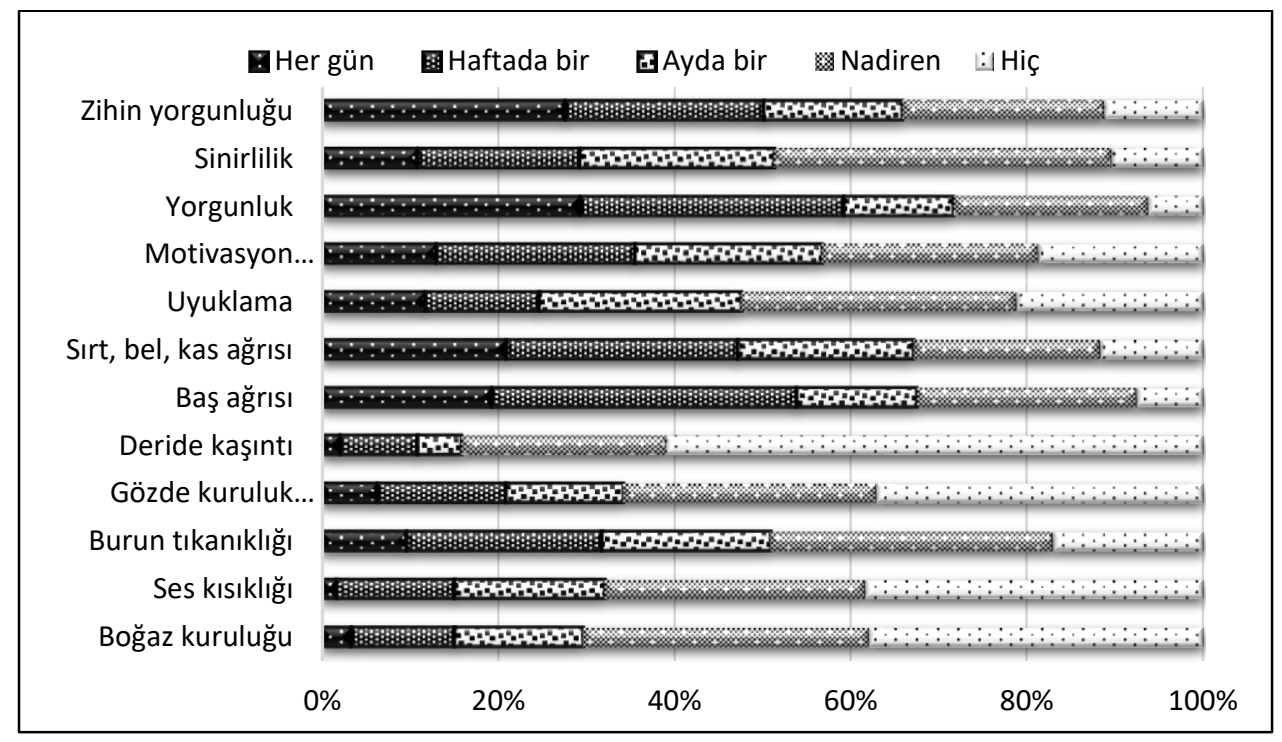

Şekil 12. Çalışma ortamından kaynaklanabilecek sağlık semptomlarının görülme sıklı̆̆ 
Sağlık üzerindeki etkilerin görülme sıklı̆̆ının değerlendirildiği anketin dördüncü bölümünde çalışma ortamı kaynaklı baş ağrısı görülme sıklığı katılımcıların \%19,2'sinde her gün, \%34,6'sında ise haftada bir olarak dikkate değer bir sıklıktadır. Sirt, bel, boyun, eklem ve kas ağrıları görülme sıklığı anket katılımcılarının yaklaşık \%67'sinde sıklıkla izlenmiştir. Uyuklama belirtisinin katılımcıların yaklaşık \%20'sinde, sinirlilik \%29'unda motivasyon eksikliğinin ise yaklaşık \%35'inde sık görülen bir etki olduğu görülmektedir. Katılımcılarda yorgunluk hissi ve zihin yorgunluğu görülme sıklı̆̆ 1 yaklaşık \%50'sinde önemli düzeyde bulunmuştur. Bu duruma elektrostatik etki, kullanıcıların gün 1şığından yararlandıkları süresinin kısa olması, yapay ışık kaynaklarının olumsuz etkisi neden olarak gösterilebilir (Şekil 12).

Hasta bina sendromunda (HBS) sıklıkla karşılaşılan belirtiler örnek yapıda uygulanan anket soruları ile değerlendirildiğinde yorgunluk, baş ağrısı, eklem ve kas ağrıları, aşırı zihin yorgunluğu, motivasyon eksikliği, sinirlilik, burun tıkanıklığı ve akıntılar gibi belirtiler en sık görülenler arasında olduğu tespit edilmiştir. İçerisinde bulunulan ortamdan kaynaklanan bazı sorunlar memnuniyet durumu sorgulandığında herhangi bir olumsuzluk göstermezken belirtilere bakıldığında önemli bulgular vermektedir. Şekil 13'da sağlık problemlerinden en az üçünü her gün, haftada bir ya da ayda bir gören katılımcı oranı görülmektedir. Nadiren ve hiç cevabını verenler belirti görülmeyen olarak değerlendirilmiştir. Bu durum, insan doğasının ortama alışma sürecinin çok kısa olması ve rahatsızlık hissetmemesinin ortamın sağlıklı olduğunu göstermeyeceği sonucunu beraberinde getirmektedir. $\mathrm{Bu}$ belirtilerin biri ya da birkaçı sıklıkla izleniyorsa içinde bulunulan ortam kaynaklı bazı etkiler olacağı göz önünde bulundurulmalıdır.

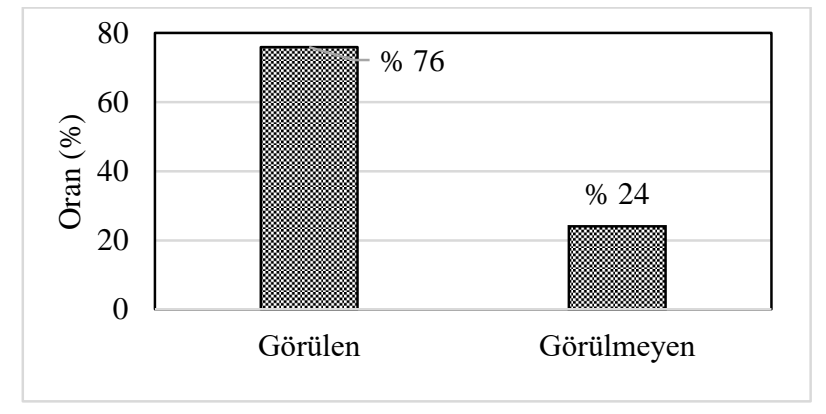

Şekil 13. Sağlık problemlerinden en az üçünün her gün, haftada bir veya ayda bir görülme durumu.

Sağlık semptomlarının görülme sıklığı ile ilgili soruların Cronbach Alfa değeri 0,914 olarak hesaplanmıştır. $\mathrm{Bu}$ değer soruların ölçme düzeyinin yüksek seviyede güvenilir olduğunu göstermektedir. Çalışmada yer alan sağlık semptomlarının görülme sıklığı ile ilgili soruların geçerliği, Kaiser-Meyer-Olkin (KMO) örneklem yeterliliği ölçütü ile değerlendirilmiş ve KMO değeri 0,907 olarak hesaplanmıştır. Dolayısıyla, sağlık semptomlarının görülme sıklığı ile ilgili soruların geçerliğinin mükemmel seviyede olduğu görülmüsşür.

Katılımcıların çalıştıkları kategoriye göre sağlık semptomlarının görülme sıklığı değişkenleri arasındaki Kruskal-Wallis Testi sonuçları aşağıdaki tabloda verilmiştir. 
Tablo 6. Katılımcıların çalıştıkları kategoriye göre să̆lık semptomlarının görülme sıklı̆̆ değişkenleri arasındaki Kruskal-Wallis Testi sonuçları

\begin{tabular}{|c|c|c|c|c|c|c|}
\hline \multirow{3}{*}{$\begin{array}{l}\text { Bağımlı } \\
\text { Değişken }\end{array}$} & Bağımsız Değisken & \multicolumn{3}{|c|}{ Ortalama } & \multirow{3}{*}{ Sig. } & \multirow[b]{2}{*}{ Açıklama } \\
\hline & & $\mathbf{N}$ & Sira & $\chi^{2}$ & & \\
\hline & Çalışılan kategori & & & & & \multirow{12}{*}{$\begin{array}{l}\text { Katılımcıların çalıştıkları } \\
\text { kategoriye göre Boğaz } \\
\text { Kızarıklıkları, Yanmaların } \\
\text { görülme sıklığı açısından } \\
\text { çalışılan kategoriye dayalı } \\
\text { istatistiksel olarak anlamlı } \\
\text { bir farklılık vardır. }\end{array}$} \\
\hline \multirow{11}{*}{ 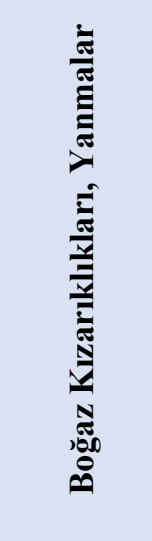 } & Hazır giyim & 76 & 111,22 & & & \\
\hline & Ayakkabı/çanta & 17 & 124,82 & & & \\
\hline & Mücevher/Aksesuar & 3 & 148 & & & \\
\hline & Sağlık/Kozmetik & 9 & 107,33 & & & \\
\hline & Dekorasyon/Ev tekstili & 7 & 89,71 & & & \\
\hline & Elektronik & 23 & 113,76 & & & \\
\hline & Cafe/Restaurant & 54 & 96,48 & 40,850 & 0,000 & \\
\hline & Kitap/Kırtasiye & 2 & 227 & & & \\
\hline & Eğlence & 19 & 168,47 & & & \\
\hline & $\begin{array}{l}\text { Hizmet (Kuru temizleme, Terzi, } \\
\text { Tobacco, Oto yıkama, Banka } \\
\text { vs.) }\end{array}$ & 23 & 172,83 & & & \\
\hline & Kiosk & 7 & 121,5 & & & \\
\hline \multirow{11}{*}{ 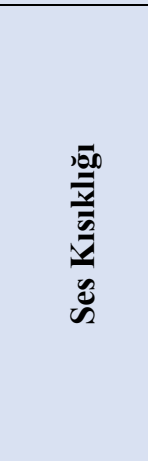 } & Hazır giyim & 76 & 110,77 & & & \multirow{11}{*}{$\begin{array}{l}\text { Katılımcıların çalıştıkları } \\
\text { kategoriye göre Ses } \\
\text { Kısıklığının görülme sıklığı } \\
\text { açısından çalışılan } \\
\text { kategoriye dayalı } \\
\text { istatistiksel olarak anlamlı } \\
\text { bir farklılık vardır. }\end{array}$} \\
\hline & Ayakkabı/çanta & 17 & 140,32 & & & \\
\hline & Mücevher/Aksesuar & 3 & 165,33 & & & \\
\hline & Sağlık/Kozmetik & 9 & 92,17 & & & \\
\hline & Dekorasyon/Ev tekstili & 7 & 81,43 & & & \\
\hline & Elektronik & 23 & 117,37 & 50,468 & 0,000 & \\
\hline & Cafe/Restaurant & 54 & 92,98 & & & \\
\hline & Kitap/Kırtasiye & 2 & 184 & & & \\
\hline & Eğlence & 19 & 189,42 & & & \\
\hline & Hizmet & 23 & 163,89 & & & \\
\hline & Kiosk & 7 & 109,07 & & & \\
\hline \multirow{11}{*}{ 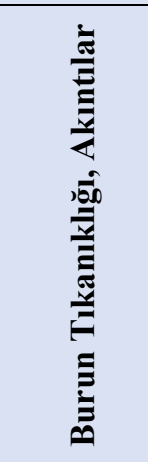 } & Hazır giyim & 76 & 125,06 & & & \multirow{11}{*}{$\begin{array}{l}\text { Katılımcıların çalıştıkları } \\
\text { kategoriye göre Burun } \\
\text { T1kanıklığı, Akıntıların } \\
\text { görülme sıklığı açısından } \\
\text { çalışılan kategoriye dayalı } \\
\text { istatistiksel olarak anlamlı } \\
\text { bir farklılık vardır. }\end{array}$} \\
\hline & Ayakkab1/çanta & 17 & 109,41 & & & \\
\hline & Mücevher/Aksesuar & 3 & 101,17 & & & \\
\hline & Sağlık/Kozmetik & 9 & 93,94 & & & \\
\hline & Dekorasyon/Ev tekstili & 7 & 135,43 & & & \\
\hline & Elektronik & 23 & 128,65 & 31,625 & 0,000 & \\
\hline & Cafe/Restaurant & 54 & 90,1 & & & \\
\hline & Kitap/Kırtasiye & 2 & 210,25 & & & \\
\hline & Eğlence & 19 & 130,66 & & & \\
\hline & Hizmet & 23 & 171,93 & & & \\
\hline & Kiosk & 7 & 110,93 & & & \\
\hline \multirow{11}{*}{ 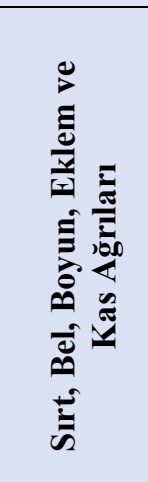 } & Hazır giyim & 76 & 118,95 & & & \multirow{11}{*}{$\begin{array}{l}\text { Katılımcıların çalıştıkları } \\
\text { kategoriye göre Sırt, Bel, } \\
\text { Boyun, Eklem ve Kas } \\
\text { Ağrılarının görülme sıklığı } \\
\text { açısından çalışılan } \\
\text { kategoriye dayalı } \\
\text { istatistiksel olarak anlamlı } \\
\text { bir farklılık vardır. }\end{array}$} \\
\hline & Ayakkabı/çanta & 17 & 148,15 & & & \\
\hline & Mücevher/Aksesuar & 3 & 86,5 & & & \\
\hline & Sağlık/Kozmetik & 9 & 57,22 & & & \\
\hline & Dekorasyon/Ev tekstili & 7 & 161,14 & & & \\
\hline & Elektronik & 23 & 113,04 & & & \\
\hline & Cafe/Restaurant & 54 & 102,25 & 30,523 & 0,000 & \\
\hline & Kitap/Kırtasiye & 2 & 159 & & & \\
\hline & Eğlence & 19 & 127,29 & & & \\
\hline & Hizmet & 23 & 167,8 & & & \\
\hline & Kiosk & 7 & 105,86 & & & \\
\hline
\end{tabular}


Tablo 6.(devam) Katılımcıların çalıştıkları kategoriye göre sağlık semptomlarının görülme sıklı̆̆ı değişkenleri arasındaki Kruskal-Wallis Testi sonuçları

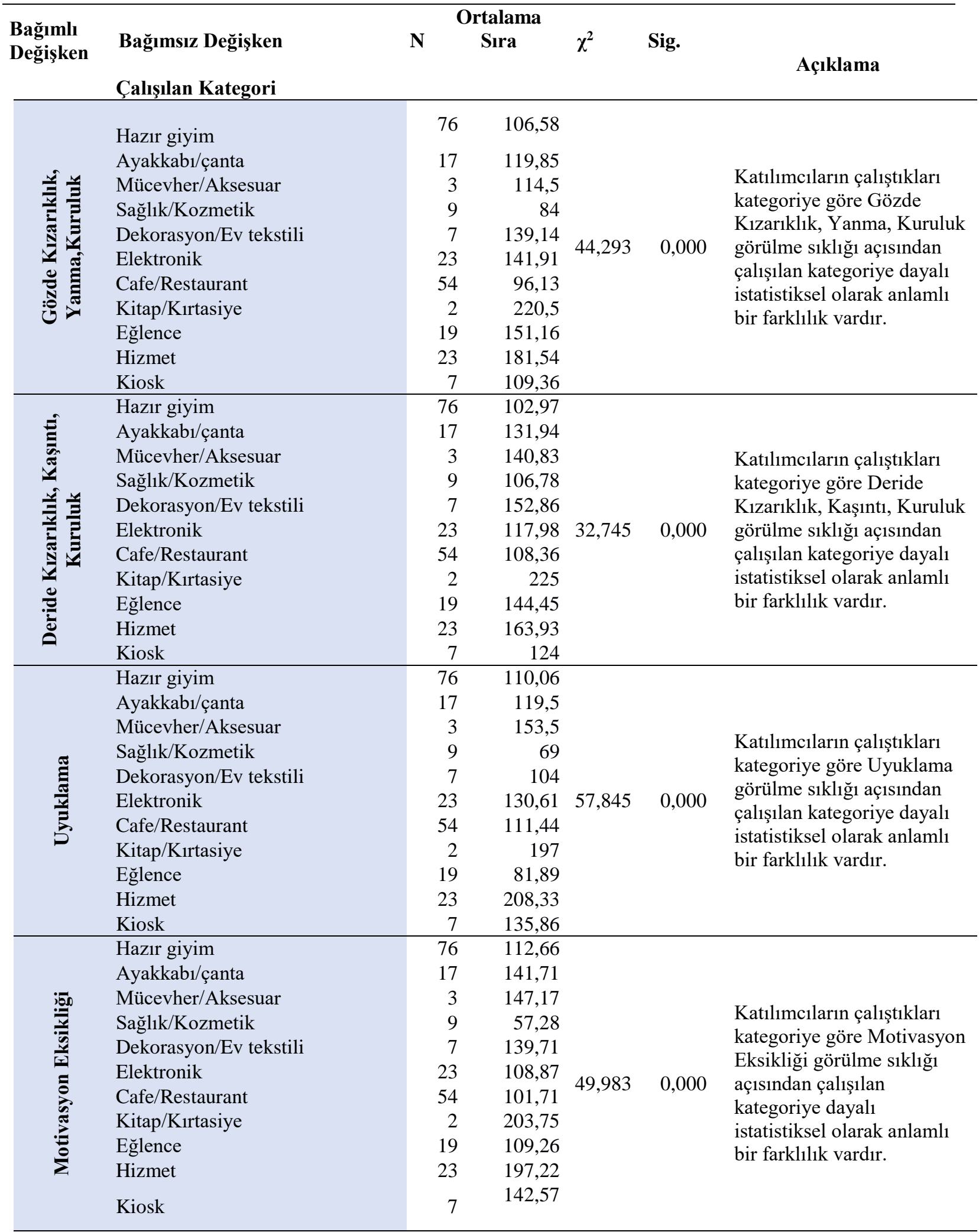


Tablo 6.(devam) Katılımcıların çalıştıkları kategoriye göre sağlık semptomlarının görülme sıklı̆̆ı değişkenleri arasındaki Kruskal-Wallis Testi sonuçları

\begin{tabular}{|c|c|c|c|c|c|c|}
\hline $\begin{array}{l}\text { Bağımlı } \\
\text { Değişsken }\end{array}$ & $\begin{array}{l}\text { Bağımsız Değişken } \\
\text { Çalışılan Kategori }\end{array}$ & $\mathbf{N}$ & $\begin{array}{l}\text { rtalama } \\
\text { Sira }\end{array}$ & $\chi^{2}$ & Sig. & Açıklama \\
\hline 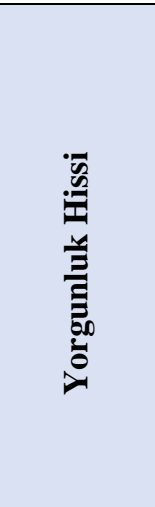 & $\begin{array}{l}\text { Hazır giyim } \\
\text { Ayakkabı/çanta } \\
\text { Mücevher/Aksesuar } \\
\text { Sağllk/Kozmetik } \\
\text { Dekorasyon/Ev tekstili } \\
\text { Elektronik } \\
\text { Cafe/Restaurant } \\
\text { Kitap/Kırtasiye } \\
\text { Eğlence } \\
\text { Hizmet } \\
\text { Kiosk }\end{array}$ & $\begin{array}{r}76 \\
17 \\
3 \\
9 \\
7 \\
23 \\
54 \\
2 \\
19 \\
23\end{array}$ & $\begin{array}{r}102,53 \\
129,79 \\
158,17 \\
65,5 \\
148,5 \\
130,28 \\
101,67 \\
205,5 \\
136,21 \\
186,98 \\
\\
147,43\end{array}$ & 46,611 & 0,000 & $\begin{array}{l}\text { Katılımcıların çalıştıkları } \\
\text { kategoriye göre Yorgunluk } \\
\text { Hissi görülme sıklığı } \\
\text { açısından çalış1lan } \\
\text { kategoriye dayalı } \\
\text { istatistiksel olarak anlamlı } \\
\text { bir farklılık vardır. }\end{array}$ \\
\hline 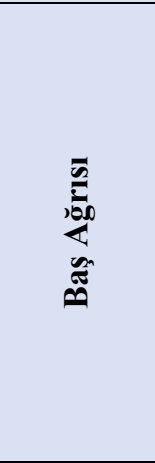 & $\begin{array}{l}\text { Hazır giyim } \\
\text { Ayakkabı/çanta } \\
\text { Mücevher/Aksesuar } \\
\text { Sağllk/Kozmetik } \\
\text { Dekorasyon/Ev tekstili } \\
\text { Elektronik } \\
\text { Cafe/Restaurant } \\
\text { Kitap/Kırtasiye } \\
\text { Eğlence } \\
\text { Hizmet } \\
\text { Kiosk }\end{array}$ & $\begin{array}{r}76 \\
17 \\
3 \\
9 \\
7 \\
23 \\
23 \\
54 \\
2 \\
19 \\
23 \\
7\end{array}$ & \begin{tabular}{r|}
101,55 \\
124,5 \\
174,17 \\
69,89 \\
131,93 \\
139,98 \\
105,63 \\
217,5 \\
154,87 \\
155,26 \\
162,71 \\
\end{tabular} & 36,137 & 0,000 & $\begin{array}{l}\text { Katılımcıların çalıştıkları } \\
\text { kategoriye göre Baş Ağrısı } \\
\text { görülme sıklığı açısından } \\
\text { çalışllan kategoriye dayalı } \\
\text { istatistiksel olarak anlamlı } \\
\text { bir farklılık vardır. }\end{array}$ \\
\hline 告 & $\begin{array}{l}\text { Hazır giyim } \\
\text { Ayakkabı/çanta } \\
\text { Mücevher/Aksesuar } \\
\text { Sağllk/Kozmetik } \\
\text { Dekorasyon/Ev tekstili } \\
\text { Elektronik } \\
\text { Cafe/Restaurant } \\
\text { Kitap/Kırtasiye } \\
\text { Eğlence } \\
\text { Hizmet } \\
\text { Kiosk }\end{array}$ & $\begin{array}{r}76 \\
17 \\
3 \\
9 \\
7 \\
23 \\
54 \\
2 \\
19 \\
23 \\
7\end{array}$ & $\begin{array}{r}116,82 \\
118,44 \\
204,17 \\
60,5 \\
125 \\
135,07 \\
108,56 \\
107,75 \\
135,89 \\
149,5 \\
113,07 \\
\end{array}$ & 20,599 & 0,000 & $\begin{array}{l}\text { Katılımcıların çalıştıkları } \\
\text { kategoriye göre Sinirlilik } \\
\text { görülme sıklığı açısından } \\
\text { çalışllan kategoriye dayalı } \\
\text { istatistiksel olarak anlamlı } \\
\text { bir farklılık vardır. }\end{array}$ \\
\hline 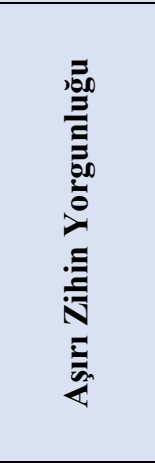 & $\begin{array}{l}\text { Hazır giyim } \\
\text { Ayakkabı/çanta } \\
\text { Mücevher/Aksesuar } \\
\text { Sağllk/Kozmetik } \\
\text { Dekorasyon/Ev tekstili } \\
\text { Elektronik } \\
\text { Cafe/Restaurant } \\
\text { Kitap/Kırtasiye } \\
\text { Eğlence } \\
\text { Hizmet } \\
\text { Kiosk }\end{array}$ & $\begin{array}{r}76 \\
17 \\
3 \\
9 \\
7 \\
7 \\
23 \\
54 \\
2 \\
19 \\
23 \\
7\end{array}$ & $\begin{array}{r}99,22 \\
116,09 \\
167,5 \\
65,61 \\
157,86 \\
135,89 \\
105,17 \\
177,5 \\
146,11 \\
187,22 \\
138\end{array}$ & 48,005 & 0,000 & $\begin{array}{l}\text { Katılımcıların çalıştıkları } \\
\text { kategoriye göre Aşırı Zihin } \\
\text { Yorgunluğu görülme sıklığı } \\
\text { açısından çalışlan } \\
\text { kategoriye dayalı } \\
\text { istatistiksel olarak anlamlı } \\
\text { bir farklılık vardır. }\end{array}$ \\
\hline
\end{tabular}




\section{SONUCLAR VE TARTISMA}

Uygulanan anket çalışmasından elde edilen bulgular doğrultusunda AVM çalışanlarının cinsiyet durumu neredeyse eşit bir dağılımda, büyük bir çoğunluğu 18-37 yaş arası genç çalışandan oluşmaktadır. Çalışanlarının çoğunluğu bekârdır ve kronik hastalığa sahip olma oranı \%1,3-4,2 arasında olup, \%35'inin sigara kullandığı tespit edilmiştir.

Isıl konfor koşulları değerlendirildiğinde çalışanların büyük bir yüzdesinin çalıştığı ortamı olumlu olarak değerlendirdiği ancak kat dağılımlarına bakıldığında özellikle bodrum katlarda memnuniyet durumunun önemli oranda azaldığı görülmüştür. Çalışma sadece kış koşullarında gerçekleştirilmiş olup sorulan sorularla yaz dönemi konfor değerlendirilmesi istenmiştir. Bu doğrultuda yaz ve kış mevsimi arasında 1s1l konfor memnuniyet durumunda önemli bir fark izlenmemiştir. Ayrıca ASHRAE 55'e göre kullanıcıların \%80'inin, TS EN ISO 7730'a göre ise \%90'ının ortam koşullarından memnun olduğu durum konforlu olarak kabul edilmektedir [9, 13]. AVM çalışanlarının \%26,7'si isıl konfordan memnun değildir. Bu durumda AVM ısıl konfor koşullarının uygun olmadığı sonucunu ortaya koymaktadır.

İç hava kalitesi açısından değerlendirmede, çalışanların \%21-37 oranında ortamda yetersiz temiz hava olduğu ayrıca toz ve kokudan rahatsızlık duyduğu, diğerlerinin ise iç hava koşullarından herhangi bir rahatsızlık hissetmediği görülmektedir. Katılımcıların çalıştığı birimin fonksiyonuna bağlı olarak bu değerlendirmenin farklılık gösterdiği izlenmiştir. Özellikle bodrum katlarda çalışanlarda, ayrıca kafe/restoran, hazır giyim ve ayakkabı/çanta mağazalarında olumsuz etkilerin daha sık görüldüğü söylenebilir. Bu durumun mağaza duvar, döşeme kaplamaları gibi bitiş malzemeleri ve dekorasyonda kullanılan ve ticaret nesnesi olarak satılan ürünlerden kaynaklı bir durum olduğu düşünülmektedir. İç ortam sıcaklığı ve nemlilik düzeyinin, kullanıcılar için uygun değerde olmamasının büyük ölçüde mukozal sağlık sorunlarına yol açtığı bilinmektedir [61]. Ayrıca iç ortam havasının tozlu olması ve rahatsız edici koku bulunması kullanıcılarda astım, boğaz kızarıklığı, yanma, nefes alma zorluğu, burun tıkanıklığı ve akıntısı, öksürük, hapşırık, nefes darlığ1 gibi solunum sistemi rahatsızlıklarına, göz iritasyonu, yorgunluğu ve kuruluğu, baş ağrısı, baş dönmesi, gerginlik, sinirlilik, konsantrasyon zorluğu, depresyon gibi psikolojik rahatsızlıklara, cilt kuruluğu ve cilt kaşıntısı gibi cilt problemlerine, karın ağrısı ve mide bulantısına yol açtığı bilinmektedir [62-65].

Görsel konfor ile ilgili değerlendirme de çalışanların büyük bir çoğunluğunun (\%65) çalışma saatleri içerisinde yeterli düzeyde doğal 1şıktan faydalanamadığı görülmüştür. Yetersiz aydınlık mekânlar ve yapay ışık kaynakları ile sağlanmış gereğinden fazla aydınlık mekânlar özellikle uzun vadede sağlık üzerinde fizyolojik ve psikolojik etkiler gösterebilecektir. Bu etkilerden bazıları göz yorgunluğu, baş ağrısı, anatomik duruş bozuklukları ve bunlar kaynaklı eklem ağrıları, halsizlik, motivasyon eksikliği ve iş veriminin düşmesidir. Görsel konfor sağlanamadığında kişinin sirkadyan döngüsünün değişimine yol açarak, hormonal sistemde olumsuz etkiler görüldüğü de bilinmektedir [66-69].

İşitsel konfor açısından yapılan değerlendirmede çalışanların \%80'inin işitsel konfor düzeyinden memnun olmadığı görülmektedir. Gürültü kaynağı olarak çoğunlukla iç ortam kaynaklı müzik ve insan sesi gösterilmektedir. Özellikle hazır giyim ve kafe/restoran fonksiyonlarında bu etkinin daha belirgin olduğu görülmüştür. İşitsel konfor uygun olmadığında maruziyet yaşayanlarda duyma problemleri, kardiyovasküler rahatsızlıklar, sindirim sistemi bozuklukları, stres, depresyon, motivasyon bozuklukları, dikkat dağınıklı̆̆ı, anksiyete, uyku bozuklukları olasıdır [70-72].

Katılımcıların \%76'sında en az üç sağlık probleminin her gün, haftada bir veya ayda bir görüldüğü tespit edilmiştir. AVM çalışanlarında ortam kaynaklı görülme olasılığı yüksek olan sağlık etkileri araştırıldığında ise, boğaz kızarıklığı, yanma, ses kısıklığı ve deride kızarıklık, kaşıntı, kuruluk gibi etkenlerin nadir görüldüğü ancak burun tıkanıklığı, akıntılar, gözde kızarıklık, yanma, kuruluk ve uyuklama gibi belirtilerin orta şiddetli olarak; sırt, bel, boyun, eklem ve kas ağrıları, motivasyon eksikliği, yorgunluk, baş ağrısı ve aşırı zihin yorgunluğu gibi belirtiler ise oldukça sık görülmektedir. Kullanıcılar her ne kadar 1sıl konfor koşulları konusunda olumsuz görüş belirtmeseler de sağlık üzerinde görülen etkilerin özellikle nem eksikliğinden (burun tıkanıklığı, akıntılar, gözde kızarıklık, yanma, 
kuruluk) kaynaklanan problemler olduğu görülmüştür. Yorgunluk, uyuklama, aşırı zihin yorgunluğu, sırt, bel boyun, eklem ve kas ağrıları gibi belirtilerin de aydınlatma ve yaygın elektrostatik etki kaynaklı sağlık problemleri olduğu anlaşılmaktadır. Araştırma sonuçlarına göre bu hastalıkların görülme oranı bu AVM'nin çalışanlar için HBS eğilimi gösterebileceğini ortaya koymaktadır.

Günümüzde insanlar yaşamlarının büyük bir çoğunluğunu kapalı ortamlarda geçirmekte ve ortam kaynaklı pek çok olumsuz etkenle karşı karşıya kalmaktadır. Bu çalışma kapsamında da özellikle kapalı plan tipolojisinde yer alan önemli fonksiyonlardan biri olan AVM yapılarının tercih edilme nedeni bu etkilerin diğer yapılara nazaran daha fazla görülebileceği üzerine kurulan hipotezdir. Gün ışığı insanın psikolojik sağlığını olumlu yönde etkileyici, motivasyonunu arttırıcı etkisinin yanı sıra fizyolojik olarak da hormonal dengemizin sürdürülebilirliği açısından önemlidir. Gün 1şı̆̆ından mahrum olma durumunda da sağlığı tehdit edecek olumsuz etkilerle karşı karşıya kalınacağı da açıktır. Ancak bu bulgular uzun vadede etki gösterdiğinden önemi anlaşılamamaktadır. Bu çalışma ile bu konunun önemine dikkat çekilerek, tasarım yaklaşımının sadece yapı fonksiyonu ve estetiği konularında başarı odaklı olmayıp, uzun saatler bu yapıda zaman geçiren kullanıcıların da dikkate alınarak tasarım yaklaşımı geliştirilmesi önerilmektedir. Özellikle bu tür yapılarda çalışanların çalışma saatlerinin organizasyonunda belirli düzenlemeler yapılması da tavsiye edilebilir. Alışveriş merkezi tasarımlarında tamamen yapay iklimlendirme ile 1sıtılan ve soğutulan mekânlar yerine pasif tasarım yaklaşımları ile de çözüm aranmalıdır. Ayrıca yapay aydınlatmalarda led vb. insan sağlığına olumsuz etki gösterebilecek aydınlatma armatürlerinin yerine enerji tasarrufu da sağlayabilen pencereler, çatı 1şıklıkları, çatı fenerleri, atriumlar, 1şık rafları, 1şık tüpleri, anadolik tavanlar, heliostatlar, prizmatik paneller gibi sistemlerden yararlanılması fayda sağlayacaktır. Bu durumun sirkadyan döngüyü dolayısıyla insan sağlığını olumlu etkileyebileceği bilici oluşmalıdır. Kullanıc konforu olgusunun ön planda tutulduğu yapıların sağlıklı bireyler dolayısıyla sağlıklı toplum oluşumuna büyük ölçüde fayda sağlayacağı unutulmamalıdır.

\section{IV.KAYNAKLAR}

[1] S. E. Seker, "Maslow'un ihtiyaçlar piramidi," YBS Ansiklopedisi, c. 1, s. 1, ss. 44-45, 2014.

[2] S. Habıbı, "Bina kabuğunun enerji etkin üzerine 1s1, 1şık ve ses açısından bir çalışma incelenmesi," Yüksek Lisans tezi, Fen Bilimleri Enstitüsü, İstanbul Teknik Üniversitesi, İstanbul, Türkiye, 2012.

[3] Y. Epstein ve D. S. Moran, "Thermal comfort and the heat stress indices," Industrial Healt, c. 44, s. 3, ss. 388-38, 2006.

[4] F. Şenkal Sezer, "Sağlık ocaklarında konfor koşullarının değerlendirilmesi: Bursa/Nilüfer örneği," Çukurova Üniversitesi Mühendislik Mimarlık Fakültesi Dergisi, c. 28, s. 1, ss. 197-208, 2015.

[5] G. K. Oral, A. K. Yener ve N. T. Bayazit, "Building envelope design with the objective to ensure thermal, visual and acoustic comfort conditions," Building and Environment, c. 39, ss. 281-287, 2004.

[6] M. Özdamar ve F. Umaroğullar1, "Thermal comfort and indoor air quality,"International Journal of Scientific Research, and Innovative Technology," c. 5, s. 3, ss. 90-109, 2018.

[7] İ. Atmaca ve A. Yiğit, "Isıl konfor ile ilgili mevcut standartlar ve konfor parametrelerinin çeşitli modeller ile incelenmesi," IX. Ulusal Tesisat Mühendisliği Kongresi, İzmir, Türkiye, 2009, ss. 543-555.

[8] S. C. Sekhar, "Thermal comfort in air-conditioned buildings in hot and humid climates -why are we not getting it right?," Indoor Air, c. 26, s.1, ss. 138-152, 2016.

[9] Thermal Environmental Conditions for Human Occupancy, ASHRAE Standart-55, 2013 
[10] H. Güler ve S. Ülkü, "Bitişik nizamlı villa tipi konutlarda yapısal konfor koşulları üzerine bir araştırma," Uludağ Üniversitesi Mühendislik-Mimarlkk Fakültesi Dergisi, c. 12, s. 2, ss. 97-197,2007.

[11] U. Rahle, "Desiccant kurutma ile nem kontrolü," Tesisat Mühendisliği Dergisi, s. 95, ss. 3742, 2006.

[12] C. İmanc1, "Döküm atölyelerinde termal konfor şartlarının incelenmesi," İşs sağlı̆̆1 ve güvenliği uzmanlık tezi/araştırma, T.C. Çalışma ve Sosyal Güvenlik Bakanlığı/İş Sağlı̆̆1 ve Güvenliği Genel Müdürlüğü, Ankara, 2014.

[13] Ergonomics of the thermal environment-Analytical determination and interpretation of thermal comfort using calculation of the PMV and PPD indices and local thermal comfort criteria, ISO 7730,2005 .

[14] F. Zoroğlu ve G. Zorer Gedik, "An evaluation of thermal comfort conditions in shopping malls 1n Istanbul," inInternational Research Conference on Sustainable Energy, Engineering, Materials and Environment (IRCSEEME),Newcastle, United Kingdom, 2017, ss. 1-8

[15] E. Mıhlayanlar, S. Kartal ve Ş. Y. Erten, "Yükseköğretim yapılarında 1sıl konfor şartlarının araştırılması: Mimarlık Fakültesi Örneği," Süleyman Demirel Üniversitesi Fen Bilimleri Enstitüsü Dergisi, c. 21, s. 3, ss. 917-927, 2017.

[16] A. B. Atmaca ve G. Z. Gedik, "Determination of thermal comfort of religious buildings by measurement and survey methods: Examples of mosques in a temperate-humid climate," Journal of Building Engineering, c. 30, ss. 101246, 2020.

[17] Q. J. Kwong, N. M. Adam ve S. H. Tang, "Effect of environmental comfort factors in enclosed transitional,space toward work productivity," American Journal of Environmental Sciences, c. 5, s. 3, ss. $315-324,2009$.

[18] L. Pistore, F. Cappelletti, P. Romagnoni ve A. Zonta, "Assesment of the IEQ in two high schools by means of monitoring, surveys and dynamic simulation," Energy Procedia, c. 82, ss. 519-525, 2015.

[19] Y. Yaşar, A. Pehlivan ve E. Altıntaş, "Illköğretim dersliklerinde termal konfor araştırması," VII. Ulusal Tesisat Mühendisliği Kongresi, İzmir, Türkiye, 2007, ss. 199-208.

[20] İ. Yüksek, E. Mihlayanlar ve T. E. Tıkansak, "Konut kullanıcılarının iç ortam konfor koşullarından memnuniyetlerinin tespitine yönelik bir çalışma,"12. Ulusal Tesisat Mühendisliği Kongresi, İzmir, Türkiye, 2015, ss. 2141-2149,

[21] H. Bulgurcu, N. İlten ve A. Coşgun, "Okullarda iç hava kalitesi problemleri ve çözümler," 7. Ulusal Tesisat Mühendisliği Kongresi Bildiriler Kitabı, c. 393, s. 1,ss. 601-616, 2005.

[22] B. Kurutaş, "Bir metal endüstrisindeki çalışma ortamlarının iç hava kalitesinin belirlenmesi," Yüksek lisans tezi, Fen Bilimleri Enstitüsü, İstanbul Üniversitesi, İstanbul, Türkiye, 2009.

[23] E. Yurtseven, "İki farklı coğrafi bölgedeki ilköğretim okullarında iç ortam havasının insan sağlığına etkileri yönünden değerlendirilmesi”, Doktora tezi, Sağlı Bilimleri Enstitüsü, İstanbul Üniversitesi, İstanbul, Türkiye, 2007. 
[24] O. Alptekin, "Binalarda iç hava kalitesi toz partiküllerinin iç mekân hava kalitesi üzerindeki etkilerinin incelenmesi", Yüksek lisans tezi, Fen Bilimleri Enstitüsü, Gazi Üniversitesi, Ankara, Türkiye, 2007.

[25] Y. Keskin ve O.Özyaral, “Kapalı alan atmosferinin sağlık üzerine etkileri: kakosmi (kötü koku) sendromu,"Astım Allerji İmmünoloji, s. 3, ss. 86 - 96, 2005.

[26] Y. Keskin, O. Özyaral, R. Başkaya, E.N. Lüleci, S. Avcı ve M. Susur Acar, "Bir kamu binası iç alan atmosferinin mikrobiyolojik kalitesi ve iş ortamı algısının hasta bina sendromu açısından sorgulanmas1," Astım Allerji Immünoloji, s. 3, ss. 56-67, 2005.

[27] V. Quagraine ve N.Boschi, "Behavioral changes can help prevent indoor air-relatedillness in Ghana," Building and Environment, c. 43, s. 3,ss. 355-361, 2008.

[28] P. S. Burge, "Sick building syndrome," Occupational and Environmental Medicine, c. 61, s. 2, ss. 185-190, 2004.

[29] A. H. Rowley ve S. T. Shulman, "Kawasaki Syndrome," Clinical Microbiology Reviews, c. 11, s. 3, ss. 405-414, 1998.

[30] H. Tezer ve G. Seçmeer, "Kawasaki hastalığında yenilikler," Hacettepe Tip Dergisi, s. 36, ss. 105-110, 2005.

[31] A. Tuncer ve Ö.U. Soyer, "Hasta bina sendromu," Astım Allerji Immünoloji, s. 3, ss. 97-102, 2005.

[32] EPA (U. S. Environmental Protection Agency), "Indoor Air Pollution: An Introduction for Health Professionals," s. 1-8, USA: EPA, 1994.

[33] P. Boyce, C. Hunter ve O. Howlett, The Benefits Of Daylight Through Windows, New York: Lighting Research Center, 2003.

[34] A. K. Yener, "Binalarda günışı̆̆ından yararlanma yöntemleri: çağdaş teknikler,"VIII. Ulusal Tesisat Mühendisliği Kongresi,İzmir, Türkiye, 2008, ss. 231-241.

[35] R. Ünver, "External obstructions and internal daylight illuminances," International Lighting Congress Proceedings, Istanbul, Turkey, 2001, ss. 558-566.

[36] WHO (World Health Organization),Development of a catalogue of methods: Indoor air pollution. Geneva, 2005.

[37] Y. Shang, B. Li, A. N. Baldwin, Y. Ding, W. Yu ve L. Cheng, "Investigation of indoor air quality in shopping malls during summer in Western China using subjective survey and field measurement," Building and Environment, c. 108, ss. 1-11, 2016.

[38] C. Y. Chun ve A. Tamura, "Thermal environment and human responses in underground shopping malls vs department stores in Japan," Building and Environment, c. 33, s. 2-3, ss. 151-158, 1998.

[39] P. H. Bloch, N. M. Ridgway ve S. A. Dawson, "The shopping mall as consumer habitat," Journal of Retailing, c. 70, s. 1, ss. 23-42, 1994. 
[40] W. M. Li, S. C. Lee ve L. Y. Chan, Indoor air quality at nine shopping malls in Hong Kong, in The Science of the Total Environment, D. Barcelo Culleres and Jay Gan, Ed., USA: Elsevier, 2001, ss. $27-40$.

[41] B. Elyiğit ve C. E. Ekinci, “Alışveriş merkezlerinin kış şartları için biyoharmolojik özelliklerinin incelenmesi," SDU International Journal of Technologic Sciences, c. 5, s. 3, ss. 8-17, 2013.

[42] Ş. F. Sezer, V. T. Arslan, ve A. Çatantimur, "Alışveriş merkezlerinde kullanıcı memnuniyetinin konfor koşulları açısından değerlendirilmesi: Bursa örneği," Uludağ Üniversitesi Mühendislik-Mimarlık Fakültesi Dergisi, c. 19, s. 1, ss. 81-95, 2014.

[43] H. Abdullah, Q. Meng, L. Zhao ve F. Wang, "Field study on indoor thermal environment in an atrium in tropical climates," Building and Environment, c. 44, s. 2,ss. 431-436, 2009.

[44] B. Chen ve J. Kang, "Acoustic comfort in shopping mall atrium spaces-A case study in Sheffield Meadowhall," Architectural Science Review, c. 47s. 2,ss. 107-114, 2004.

[45] E. B. Çalışkan, "AVM tipolojilerinin işitsel konforunun değerlendirilmesi," Yüksek Lisans tezi, Fen Bilimleri Enstitüsü, Orta Doğu Teknik Üniversitesi, Ankara, Türkiye, 2010.

[46] K. Demir, "Noise control and constructual preventions at shopping centers: two examples in Ankara," Yüksek lisans tezi, Fen Bilimleri Enstitüsü, Gazi Üniversitesi, Ankara, Türkiye, 2003.

[47] P. N. Dökmeci,“Acoustical comfort evaluation in enclosed public spaces with a central atrium: A case study in food court of Cepa Shopping Center," Yüksek Lisans tezi, Güzel Sanatlar Enstitüsü, Bilkent Üniversitesi, Ankara, Türkiye, 2009.

[48] Z. U. Ahmed, M. Ghingold ve Z. Dahari, "Malaysian shopping mall behavior: An Exploratory study,"Asia Pacific Journal of Marketing and Logistics, c. 19, s. 4, ss. 331- 348, 2007.

[49] M. J. Mendell ve G. A. Heath, "Do indoor pollutants and thermal conditions in schools influence student, performance? A critical review of the literature," Indoor Air Journal, c. 15, ss. 27-32, 2005.

[50] M. I. El-Adly, "Shopping malls attractiveness: A segmentation approach,"International Journal of Retail \& Distribution Management, c. 35, s. 11, ss. 936-950, 2007.

[51] J. R. DeLisle, "Shopping center classifications: challenges and opportunities," ICSC Working Paper Series, Research Review, c. 12, s. 2, ss. 96-101, 2005.

[52] Sabri Paşayiğit Architects. (2019, 1 Mayı). AVM Proje [Online] Erişim:http://www.spdo.com.tr/proje/erogluedirne-avm/177

[53] R. Altunışık, R. Coşkun, S. Bayraktaroğlu ve E. Yıldırım, Sosyal Bilimlerde Araştırma Yöntemleri, 7. bask1, Sakarya, Türkiye: Sakarya Kitabevi, 2012.

[54] K. Böke, Sosyal Bilimlerde Araştırma Yöntemleri, İstanbul, Türkiye: Alfa Yayınları, 2009.

[55] J. M. Ruane, Essentials of Research Methods: A Guide to Social Science Research, United Kingdom: Wiley-Blackwell, 2004.

[56] Ş. Kalayc1, SPSS Uygulamalı Çok Değişkenli İstatistik Teknikleri, Ankara, Türkiye: Asil Yayın Dağıtım, 2010. 
[57] İ. Seçer, SPSS ve LISREL ile Pratik Veri Analizi: Analiz ve Raporlaştırma, Ankara, Türkiye: Anı Yayınc1l1k, 2013.

[58] K. Özdamar, Paket Programlar ile İstatistiksel Veri Analizi-1, Eskişehir, Türkiye: Kaan Kitabevi, 2011.

[59] N. Gürsakal,Çıkarımsal İstatistik: SPSS-MINITAB Uygulamalı , Bursa, Türkiye: Dora Yayınc1lik2009.

[60] M. Kartal, Bilimsel Araştırmalarda Hipotez Testleri, Ankara, Türkiye: Nobel Yayın Dağıtım, 2006.

[61] P. Skov, O. Valbjorn ve B. V. Pedersen, "Influence of indoor climate on the sick building syndrome in an office environment," Scand J Work Environ Health, c. 16, s. 5, ss. 363-371, 1990.

[62] O. Alptekin ve G. Çelebi, "Toz partiküllerinin iç mekân hava kalitesi üzerindeki etkilerinin incelenmesi," Kafkas Üniversitesi Fen Bilimleri Enstitüsü Dergisi, c. 8, s. 1, ss. 30-49, 2015.

[63] A. Norhidayaha, C. Lee, M. K. Azharb ve S. Nurulwahidab, "Indoor air quality and sick building syndrome in three selected buildings," Procedia Engineering, c. 53, ss. 93-98, 2013.

[64] A. Hedge, W. A. Erickson ve G. Rubin, "Predicting sick building syndrome at the individual and aggregate levels," Environment International, c. 22, ss. 3-19, 1996.

[65] M. Hodgson, "Indoor environmental exposure and symptoms," Environmental Health Perspective, c. 110, s. 4, ss. 663-667, 2002.

[66] S. H. A. Begemann, G. J. Van Den Beld ve A. D. Tenner, "Daylight, artificial light and people in an office environment, overview of visual and biological responses," International Journal of Industrial Ergonomics, c. 20, ss. 231-239, 1997.

[67] P. R. Boyce, Human Factors in Lighting,2nded., London: Taylor and Francis, 2003.

[68] R. Küller, "The influence of light on circarhythms in humans,"Journal of Physiological Anthropology and Applied Human Science, c. 2, s. 21, ss. 87-91, 2002.

[69] J. A. Veitch ve G. R. Newsham, "Lighting quality and energy-efficiency effects on task performance, mood, health, satisfaction, and comfort,"Journal of the Illuminating Engineering Society, c. 27 , s. 1 , ss. $107-129,1998$.

[70] R. F. S. Job, "The influence of subjective reactions to noise on health effects of the noise," Environment International, c. 22, ss. 93-104, 1996.

[71] P. Knipschild, "Medical effects of aircralt noise: General practice survey," Int. Arch. Occup. Environ. Health, c. 40, ss. 197-200, 1977.

[72] E. P. Sarafino, Health Psychology: Biopsychosocial Interactions, 2nded., New York, USA: Wiley,1994. 